\title{
The Voting Prohibition in Bond Workouts
}

\author{
Mark J. Roe*
}

\begin{abstract}
Section 316(b) of the Trust Indenture Act prohibits a binding vote by bondholders to change any core term-principal amount, interest rate, or maturity date-of a bond issue. In this Article, Professor Roe shows how section 316's prohibition inhibits a troubled company's ability to reorganize outside of bankruptcy. He argues that the prohibition today fails to implement satisfactorily its original goals of individualized bondholder choice and bondholder protection. In a future recession, the prohibition could contribute to unnecessary bankruptcies. Professor Roe concludes that section 316's prohibition should be repealed.
\end{abstract}

Fifty years ago, Congress prohibited all binding bondholder votes that would modify any core term-principal amount, interest rate, and maturity date- of a bond indenture. As a result, firms in financial distress may now successfully recapitalize their outstanding bond obligations only if enough bondholders individually consent.

The current explosive use of junk bonds makes timely a reexamination of this longstanding congressional prohibition. ${ }^{1}$ In a future economic recession, some issuers of junk bonds will be forced to seek financial reorganization; similarly, some issuers of investment grade bonds will experience severe reverses and also seek reorganization. Firms that promise heavy fixed payments will find themselves under financial stress if their earnings decline and cash is otherwise unavailable to service the debt. A

* Professor, University of Pennsylvania Law School. B.A. 1972, Columbia; J.D. 1975, Harvard. Thanks go to Franklin Allen, Allan Axelrod, Lucian Bebchuk, Victor Brudney, Frank Buckley, Stephen Burbank, David Carlson, Daniel Fischel, Jeffrey Gordon, Homer Kripke, Howard Latin, Morey McDaniel, Elizabeth Miller, Robert Mundheim, Roberta Romano, David Shakow and participants in workshops at the University of Pennsylvania, the University of Virginia, and Yale for comments on an earlier draft, and to the University of Pennsylvania's Law and Economics Institute for research assistance.

1. Congressional Research Service, 99th Cong., ist Sess., The Role of High Yield Bonds (Junk Bonds) in Capital Markets and Corporate Takeovers: Public Policy Implications, A Report for the USE of the Subcomm. on Telecommunications, Consumer Protection, and Finance of the House Comm. on Energy and Commerce 20, 33 (Comm. Print 1985) [hereinafter HousE JUNK BOND REPORT]. Junk bonds, or high-yield securities, are publicly-issued debt lacking an investment grade rating, promising high interest payments, and having a nontrivial chance of default. Junk bonds were once "fallen angels," bonds issued by good credits that subsequently declined. The recent explosion has been of bonds that are risky at issuance. The lowrated bond has become another primary source of capital. By some measures junk bonds now constitute one quarter of new corporate public debt. Id. at 21. 
workout, in which the unserviceable debt is exchanged for stock or in which payments are stretched out, would then be necessary. If a workout fails, bankruptcy may ensue. ${ }^{2}$

Financial stress disrupts the firm's relationships with its suppliers, its customers, its managers, and its workers, all of whom prefer more secure alternatives. Costs are borne not just by the firm: A protracted, unsuccessful workout or a bankruptcy imposes costs, both psychological and monetary, on the firm's managers and employees. Effects ripple through the larger pool in which the firm does business. More prosaically, the economic deterioration produces conflict over how to recapitalize the failing firm.

Against this backdrop, I examine in this Article whether and how current bond regulation of workouts could be reformed to reduce the costs of financial collapse. In Section I, we see how financial stress creates problems that current bond regulation exacerbates. Although a distressed firm usually will operate better if it can alter its financial structure, the financial stress makes the task of recapitalization-raising new capital, renegotiating terms with creditors, or merging with another firm-more difficult. Greditors that refuse to participate in the workout will benefit, because the firm more easily can pay residual creditors in full after (and if) the recapitalization succeeds. The holdouts would benefit disproportionately, at the expense of those who would provide new capital, renegotiate their credits or make the merger offer. Creditors, as a group, and the firm cannot easily resolve the resultant deadlocks. ${ }^{3}$

2. Junk bonds heighten related macroeconomic risks, some argue, because Federal Reserve officials might not take otherwise desirable anti-inflationary measures if they are fearful of junk bondinduced bankruptcies. See, e.g., B. Friedman, InCREasing Indebtedness and Financial StabilITY IN THE United STAtes 22 (National Bureau of Economic Research Working Paper No. 2072, 1986); Advice for Investors, Barron's, July 8, 1985, at 15, col. 1, 30, col. 5 (interview with Donald Kurtz).

Other systemic issues arise from the persistent problem of risk externalization by insured financial institutions. Junk bonds provide high current income, paid for with an increased risk of loss in a future default. Usually that trade-off is a matter of investor preference for risk, assuming the investor is properly informed. Individual investors may not always understand those risks. Also, they may not see the pitfalls in the mutual fund's construction of its own value when the securities it owns do not trade regularly, or the uncertainty in the fund's income based on accrued, but unpaid, bond interest. Informed managers and owners of insured financial institutions may prefer to take on future risks in return for substantial current income, thereby preventing for the time being a government-required merger or other intervention. The insured financial institutions will thereby place some of the longrun default risk onto public insurance funds. See Issues Relating to High-Yield Securities (Junk Bonds): Hearings Before the Subcomm. on General Oversight and Investigations of the House Comm. on Banking, Finance and Urban Affairs, 99th Cong., 1st Sess. 30, 31, 59 (1985) [hereinafter House Junk Bond Hearings]. Currently, junk bonds compose only a small part of the aggregate holdings of such insured institutions. For example, they amount to only $0.4 \%$ of federal thrift associations' assets. House Junk Bond Hearings, supra, at 98-99.

3. A simple buoying-up scenario: You and I each lent $\$ 1.00$ to a firm worth $\$ 10.00$ at the time of the loan. The firm unexpectedly declined in operational value. Today it is worth $\$ 1.00$. Each loan has a face value of $\$ 1.00$, but its real value cannot be more than 50 cents. The firm approaches both of us with a recapitalization plan. We are each asked to exchange our $\$ 1.00$ bond for about $50 \%$ of the 
This general buoying-up effect affects all creditors; to overcome it, nearly equal treatment of creditors is necessary. ${ }^{4}$ Completely equal treatment of bondholders is, as a practical matter, impossible in a workout, since regulation prohibits a binding vote among them. Workably equal treatment of bondholders will require near unanimity, a condition not readily attainable without mechanisms that distort the natural incentives to hold out.

In Section II, I critically examine the Trust Indenture Act's prohibition of a bondholder vote in a workout. William O. Douglas, the principal architect of the prohibition and of the governing corporate bankruptcy framework that endured until 1978, offered bondholder protection as the rationale for prohibiting votes. Douglas and his colleagues at the SEG were not only aware that requiring near unanimity would help induce bankruptcy, they welcomed the prospect. They were convinced that insider machinations would damage bondholders and that the only cure was a bankruptcy proceeding in which the judge scrutinized the recapitalization.

But in the half-century since the prohibition's enactment both the bond market and bankruptcy reorganizations have changed considerably from the SEC's perception of them in the 1930's. Regarding bankruptcy, Douglas' rationales and their concomitant protective framework were shattered by the 1978 Bankruptcy Code, ${ }^{5}$ which encourages negotiated solutions by majority vote, the very kind of vote prohibited under the Trust Indenture Act. Furthermore, the prohibition of bondholder votes provides little protection in today's heavily institutionalized bond market. Better ways can be found to accomplish the little that the prohibition now achieves. The prohibition is also sharply at odds with prevailing mechanisms of assent in other corporate recapitalizations, such as stockholder votes in mergers and preferred stockholder votes in recapitalizations.

Douglas' concern with bondholder protection today would focus on different matters. As financial markets reticulate, new and more complex intermediaries channel funds from the savings of upper middle class families to the corporation. The interposition of these new agents creates fidu-

firm's common stock. If you go along with the plan, but I do not, most of the firm's value will shift to me. The firm, worth about $\$ 1.00$, can just barely pay off my $\$ 1.00$ claim after you trade in your claim as a creditor for new stock. Even if you take nearly all of the stock, the value of your stock is still nearly nothing. I will be "buoyed up" at your expense by the exchange. You will lose your priority, i.e., your right to interest payments before stockholders receive dividends and your right to be paid before stockholders in the event of bankruptcy. Since I did not give up my priority, I will be paid before all stockholders, including you. Experienced bankers and their counsel will anticipate this effect, and, before "giving up their priority," will insist on an "equality of sacrifice," requiring that others agree to a similar exchange as a condition precedent to the exchange.

4. That is, creditors with the same priority arrangement would be treated equally, but subject to previously-established unequal priority arrangements. An alternative to the equal treatment of creditors at the same priority contemplates structuring the recapitalization to damage the holdouts and to benefit the agreeing bondholders; not all recapitalizations can be so structured. See infra Section I-D.

5. Bankruptcy Reform Act of 1978, 11 U.S.C. §§ 101-151326 (1982). 
ciary concerns similar to those that Douglas had in the 1930's: When business failure provokes a change in the flows to bondholders and suggests a renegotiation of a bond indenture, these institutional agents may prove faithless to their principals. The tension between protection and flexibility may be intractable, but the new risks of insider machinations are not dealt with effectively, if at all, by the prohibition of majority action clauses. While bondholder protection through regulation of the indenture's terms governing recapitalizations may be suitable, the prohibition of majority action clauses itself provides little protection. Indeed, the prohibition does not prevent the distorted bondholder choices that arise in reaction to, or despite, the voting prohibition. A sensible response would be to repeal the prohibition and, although serious distortions could be expected to disappear through eventual contractual demands of bondbuyers, replace it with a simple and flexible standard, implemented by SEC rulemaking, prohibiting fraud and distortion in bond recapitalizations.

In Section III, I examine these alternative methods of indenture regulation and bondholder protection. While simple repeal of the prohibition on majority votes would give rise to complex problems of information, protective renegotiation, signalling effects, and serious tax problems, these difficulties are not all intractable. The alternatives I propose here can better serve both issuers and bondholders than the current prohibition.

\section{Why WORKOUtS Collapse}

\section{A. Why Are There Bankruptcies?}

Bankruptcies are thought to be expensive. The fundamental operational decline reduces sales and profits, but the financial stress of bankruptcy deepens these losses. Consumers hesitate to buy from a shaky company that may not survive to service its warranties and provide spare parts. Skilled managers depart. Those that stay have their attention diverted from operations to guiding the firm through bankruptcy. Sometimes operations thought to be otherwise worthwhile are shut down or sold to satisfy creditor demands for immediate repayment. Investment and operational strategies may be distorted. Direct payments to lawyers and investment bankers are not trivial. Moreover, the need to apply to a court for approval of some decisions slows the firm down. ${ }^{6}$ Financial distress short of

6. See Gordon \& Malkiel, Corporation Finance, in How TAXes AfFect Economic BeHavior 131, 135-38 (H. Aaron \& J. Pechman eds. 1981); Blum, Corporate Reorganization Doctrine As Recently Applied by the Securities and Exchange Commission, 40 U. CHI. L. REv. 96, 96-97 (1972); Warner, Bankruptcy Costs: Some Evidence, 32 J. Fin. 337, 339 (1977) ("[P]otential users of the [bankrupt's] product . . . use their perception of the firm's financial condition to evaluate its operating characteristics."); see, e.g., Hicks, A Steel Strategy Backfires, N.Y. Times, July 18, 1986, at D1, col. 2 (LTV Corporation, a company heavily laden with junk bonds and pension obligations, files for bankruptcy, inducing "experts and analysts [to] argue [that the steel division might] cut prices below current industry levels in a desperate push to . . . hold onto skittish customers.").

Much of the suspicion that bankruptcy costs are large comes from finance theory, which posits that 
bankruptcy also will produce most of these costs until the stress is eliminated. But a typical bond recapitalization, if successful, can take three months, ${ }^{7}$ while a bankruptcy reorganization typically takes two or three years. ${ }^{8}$

Why don't the owners and creditors of the firm negotiate a deal to avoid bankruptcy? Ronald Coase's famous theorem suggests that, in the absence of transaction costs, the incentives of those financially interested in the nearly bankrupt firm would be to contract to the efficient solution. ${ }^{9}$ Creditors could take a large stock position or reduce required current cash payments in return for a greater deferred return. In the workout, they could then split among themselves (and perhaps with stockholders) the savings in bankruptcy costs. Creditors and stockholders frequently make that attempt, sometimes succeeding, but often failing. The failures that will concern us are those caused by the buoying-up effect.

\section{Holdouts and the Buoying-up Effect}

In a workout affecting bondholders, the company asks the bondholders to exchange their bonds for stock or for bonds with different terms. In a basic exchange offer, ${ }^{10}$ bondholders that do not exchange will be enriched at the expense of those that do: The exchange will leave the company able to pay the diminished fixed debt to the holdout bondholders in full. Indeed, the exchanging bondholders might be made worse off, since they help assure payment to the holdouts. If the subsidy to the nonexchanging bondholders is greater than their savings in avoided bankruptcy costs, each bondholder is better off refusing to exchange. If enough bondholders refuse, they will frustrate the workout.

Bondholders otherwise willing to exchange will thus condition their participation on others also exchanging. Indeed, Wall Street bond traders report that overwhelming bondholder acceptance is a usual and necessary

in perfect markets, the firm cannot increase its aggregate value by altering the debt-equity mix. See Modigliani \& Miller, The Cost of Capital, Corporate Finance and the Theory of Investment, 48 AM. ECON. REv. 261, 268 (1958). But markets are not perfect, and interest payments on debt are taxdeductible while dividend payments on equity are not. This tax benefit for debt should lead the public firm that raises all its capital from outsiders to prefer debt over equity. But debt is not overwhelmingly used. Why? The standard economic explanation is that high bankruptcy costs discourage even greater use of debt. The firm trades off current tax savings until the risks of bankruptcy become too high.

7. See Wahl, Exchange Offers: Old Versus New Securities, High Performance 2 (May 1986) (Morgan Stanley memorandum).

8. E. Altman, Corporate Bankruptcy in America 4 (1971).

9. Coase, The Problem of Social Cost, 3 J.L. \& Econ. 1 (1960); Bulow \& Shoven, The Bankruptcy Decision, 9 BeLL. J. ECON. 437, 438 (1978) (Bankruptcy costs raise "primary question [of] why bankruptcy should ever occur.").

10. See infra Section I-D for a discussion of complex offers. 
condition to an effective recapitalization of a distressed company. ${ }^{11}$ The bondholders are locked in game theory's prisoners' dilemma. ${ }^{12}$

These effects are neatly captured in lawyers' admonition to creditors against "losing your priority"1s in a recapitalization and that the "principle of equality of sacrifice" ought to govern a workout." Creditor selfprotection induces creditors not to give up their priority unless there is equality of sacrifice among creditors. However, when creditors follow these maxims, they will place the distressed firm in a bind: Without near unanimity, a workout fails.

\section{Reasons for Holdouts and Bargaining Failures}

A multi-creditor workout may fail for a number of reasons, some having little to do with the presence of multiple creditors. Even a firm's at-

11. Wahl, A New Technique for Evaluating Exchange Offers 2 (Jan. 1986) (Morgan Stanley memorandum) (Usual required minimum is $85 \%$ acceptance.). See, e.g., The Flying Tiger Line, Exchange Offer Circular 1 (Feb. 16, 1984) (85\%); Oxoco Inc., Exchange Offer Circular ii (June 17, 1985) (85\%); Sharon Steel Corp., Exchange Offer Circular i (May 3, 1985) (80\%); Texas International. Co., Exchange Offer Circular 1 (June 6, 1985) (85\%); Burrough \& Moffett, Many Small Firms Are Squeezed by Fall in Crude's Price, Wall St. J., Aug. 9, 1985, at 6, col. 1 (80\% acceptance required for Crystal Oil Co.).

12. See R. Luce \& H. Raiffa, Games and Decisions 94-97 (1957). Game theorists illustrate the prisoners' dilemma with payoff matrices. These can easily be used to demonstrate the bondholders' dilemma. Payoffs are specified in each box. The left-hand payoff is the payoff for bondholder A; the right-hand payoff is for bondholder $B$.

\section{CHART 1}

\begin{tabular}{|c|c|c|c|c|}
\hline & \multirow{2}{*}{\multicolumn{2}{|c|}{$\begin{array}{c}\text { B does not } \\
\text { exchange } \\
\text { A's payoff, B's payoff }\end{array}$}} & \multicolumn{2}{|c|}{ B exchanges } \\
\hline & & & A's payoff, & B's payoff \\
\hline $\begin{array}{l}\text { A does not } \\
\text { exchange }\end{array}$ & $\$ .50$ & $\$ .50$ & $\$ 1.00$ & $0+Y$ \\
\hline $\begin{array}{l}\text { A } \\
\text { exchanges }\end{array}$ & $0+Y$ & $\$ 1.00$ & $\$ .50+Y /$ & $\$ .50+Y / 2$ \\
\hline
\end{tabular}

( $\mathrm{Y}$ is the operational gain resulting from a recapitalization.) In assessing his strategy, A will conclude that it is better not to exchange, irrespective of what $B$ does (unless $Y$ is large, in this instance, $\$ .50$ or greater). If $\$ .50$ is greater than $0+Y, A$ is better off not exchanging even if $B$ does not exchange. If $B$ does exchange, $A$ gets $\$ 1.00$ by not exchanging and would get only $\$ .50+Y / 2$ if he exchanged. Again A is better off not exchanging, as is B. Only if they mutually assure one another that they will both exchange does the exchange become worthwhile.

The prisoners' dilemma is usually a basis to intervene in the market to remove the dilemma. E. Browning \& J. Browning, Public Finance and the Price System 23 (2d ed. 1983) (Public goods and externalities justify government interference in market.); R. LuCE \& H. RAIFFA, supra, at 97. Ironically, in bond workouts the legal intervention creates the dilemma.

13. The priority lost would be the bondholder's right to be paid before stockholders in a bankruptcy, to share ratably with creditors at the same level in a bankruptcy, and, outside of bankruptcy, to receive cash payments, i.e., interest, sinking fund payments, and eventually return of principal upon maturity while stockholders receive little or nothing if the firm is insolvent.

14. Dunham \& Borowitz, The Role of the Indenture Trustee in Reorganization Cases Under the Bankruptcy Code, 102 Banking L.J. 436, 445-46 (1985); Miller, Debt Restructuring-The Dynamics of Workouts, in The Troubled LBO-When the Cash Flow Goes 6-1, 6-12, 6-15 (1986). 
tempt to restructure with a single creditor can fail. Differences of opinion, mistrust and strategic action can thwart a deal. Parties may have different estimates of the firm's future revenues, or of the dispersion in those estimates; institutional creditors may have strong preferences for one means of compensation (cash or debt) over another (stock).

Creditors may fear that management is manipulating the firm-specific information it provides to creditors in order to induce creditors to accept a disadvantageous deal. The managers may never provide erroneous information, but creditors will not know whether the information is slanted to their detriment. When this mistrust is present, completing the deal will be more difficult. ${ }^{15}$

The tactics of negotiation may also stymie a deal. The parties have a gain to split-the avoided costs of bankruptcy and continuing financial stress-but they have no ready-made guide for dividing the savings. The gain can be obtained only by mutual consent. But what if one side asks for $90 \%$ of the gain as a precondition to consent? Valuable time may be lost thrashing out the bargain in a strategic setting. ${ }^{16}$

Multi-creditor bargains present more pernicious problems because the buoying-up effect worsens the foregoing bargaining failures. Even when a single creditor and the firm overcome these impediments, they cannot readily strike their own deal and ignore the other creditors, because value will flow from the consenting creditor to the holdout creditors.

This increased complexity usually affects all creditors. Bondholder holdouts stand to benefit at the expense not only of other bondholders but of all the company's creditors. Therefore, non-bondholder creditors will often be unwilling to agree to a recapitalization without substantial bondholder participation as well.

15. However, stock-for-debt offers alleviate some mutual mistrust problems. If insider stockholders falsely assert that the firm is on the brink of bankruptcy, the falsely grim picture affects the perceived value of both the bonds and the common stock that is being "sold" to the bondholders. Hence, the stockholders must offer an unduly large portion of the common stock to the bondholders. Bondholders might mistakenly exchange undervalued bonds, but the exchange would be for similarly undervalued stock. Furthermore, when the stockholders obtain a small percentage of the restructured common stock, the room for effective misrepresentation is reduced. That a stock-for-debt exchange reduces the possibility of cheating is significant in that a crucial rationale for the prohibition on majority action was a belief that bondholders would be cheated. See infra Section II.

However, misinformation that favored one group of creditors, for example the firm's bankers, over another creditor group would not be fully controllable by a stock-for-debt exchange. Furthermore, if the bondholders stretch out the maturity of their bonds or reduce interest in a debt-for-debt exchange, the bondholders could mistakenly give up undervalued bonds but fail to get undervalued stock. Hence the quandary: Although a debt-for-debt exchange reduces the buoying-up problem because priorities are not given up, it increases the informational mistrust problem. A stock-for-debt exchange has the contrary benefit and detriment.

Institutional bondholders presumably sense the information problem and will evaluate proposals to exchange bonds for stock differently than proposals to stretch out the maturity or reduce the principal amount of their bonds. $C f$. R. Reich \& J. Donahue, New Deals: The Ghrysler Revival and THE AMERICAN SySTEM 178, 253-55 (1985) (Bank creditors receive warrants in Chrysler recapitalization; warrants later become very valuable.).

16. See, e.g., J. Friedman, Oligopoly and the Theory of Games (1977). 
The buoying-up effect in combination with any of the other recapitalization problems can be fatal to a deal. If enough creditors have optimistic expectations, mistrust managerial or stockholder representations, or seek a greater portion of the gains of recapitalization, then other creditors may recognize the buoying-up effect and, in defense of their own interests, also hold back consent. When parties bargain under uncertainty, the inability to assure equality could destroy a focal point at which the bargaining parties might meet. ${ }^{17}$ That is, each creditor may have her own reservation price, subject to the focal point condition that no equal-ranking creditor obtains more. The norm used in recapitalizations that the "principle of equality" should govern may reflect a search for a focal point for agreement. The inability to treat bondholders equally could first stymie bondholder acceptance and then shatter a focal point to which all creditors may be converging. ${ }^{18}$

Finally, bondholders may seek to use the buoying-up effect offensively. By withholding consent to the recapitalization a bondholder may hope to gain from the buoying-up by seeing the economic value of her bonds increase if the recapitalization succeeds. But if many bondholders think the same way and act strategically, while hoping the other bondholders consent to the deal, then the deal will collapse. Furthermore, even if only a few act strategically, their holdout, combined with the unresponsive, optimistic, and mistrusting bondholders may induce others to act defensively to protect themselves from the buoying-up effect. Again, the deal collapses.

\section{Regulation and the Necessity of Near Unanimity}

Surely issuers, investment banks selling bonds, major bondholding institutions, and their respective legal counsel must have recognized the usefulness of bondholder collective action over the course of decades and billions of dollars in bond issues. A vote could allow bondholders to act as a single creditor, thereby eliminating a crucial source of multi-creditor bargaining failure. ${ }^{19}$ Strong evidence indicates that those involved in reorganizations

17. See T. Schelling, The Strategy of Conflict 54-55, 58-59, 106-07 (1960).

18. To illustrate: With an eye on the holdouts, some creditors may simply be unwilling to allow "peer" creditors to obtain a better deal. They also may doubt their own conclusions about the rationality of the deal if they see knowledgeable creditors holding out. In a bureaucratic context, the loan officer may have difficulty justifying a recapitalization to others in the organization if they know that other institutions are not going along.

Other difficulties arise. The few individuals left in the bond market may be difficult to find or be unresponsive. When a bondholder's stake is small in relation to her wealth, she may see the request for action as a nuisance. If the recapitalization is complex, the value of an investor's time or the cost of expert advice could deter action.

19. Of course, single-creditor bargaining failures would remain. Further, since the declining firm could also have bank loans, an insurance company private placement, or other bond issues, the threecreditor groups could produce a multi-creditor bargaining failure. Nevertheless, a bondholder vote would eliminate a critical source of failure. 
have long recognized the usefulness of the majority action clause in facilitating a workout. ${ }^{20}$

Although the Trust Indenture Act ${ }^{21}$ prohibition is sufficient to explain the lack of majority action, there may be other explanations. Creditors may want to have an individualized veto over a workout or bondbuyers may prefer bonds without a majority action clause. If bankruptcy costs are seen as low and the advantages of veto high, then majority action clauses might not arise even if permitted. However, economic and historical evidence indicates that the absence of the clause in public bond indentures is not necessarily explained by either uselessness of the clause or creditor demand for an individualized veto. Therefore I shall defer for now more detailed examination of these possibilities. ${ }^{22}$

20. See Hearings on H.R. 2191 and H.R. 5220 Before a Special Subcomm. of the House Comm. on.Interstate and Foreign Commerce, 67th Cong., 1st Sess. 145, 161 (1939) [hereinafter House Hearings I] (statement of Harold V. Amberg, General Counsel, First National Bank of Chicago) ("ID]enial [to] security holders [of] group action [by vote] will automatically discourage any attempts at voluntary reorganizations which [may otherwise be] possible."); id. at 65,83 (statement of John K. Starkweather, Chairman of Legislation Comm. of Inv. Bankers' Assoc.) (statement to similar effect); id. at 237, 284 (statement of Edmund Burke, Jr., Assistant Director, Reorganization Division of SEC) (Proposed prohibition of majority action clauses "ha[s] drawn considerable fire."); A. DEwING, The Financial Policy of Corporations 175-76 (5th ed. 1953); J. Rosenberg, Corporate Reorganization and the Federal. Court vii, 11, 32-34, 94-95 (1924); Cravath, The Reorganization of Corporations; Bondholders' and Stockholders' Protective Committees; Reorganization Committees; and the Voluntary Recapitalization of Corporations, in SOME Legal Phases of CoRporate Financing, Reorganization and Regulation 153, 203 (1917) [hereinafter CoRporate Financing]; Rosenberg, Reorganization-The Next Step, 22 Colum. L. Rev. 14 (1922); Swaine, Reorganization-The Next Step: A Reply to Mr. James N. Rosenberg, 22 Colum. L. Rev. 121 (1922); Note, The Rights and Remedies of the Bondholder Under Corporate Bonds and Indentures: II, 27 Col.um. L. REv. 579, 586 (1927) ("The most vexatious problem in corporate reorganization has been to overcome the opposition to the reorganization plan of minority bondholders.").

As depression-era workouts failed, demand for majority action clauses increased. See SEC, REPORT on the Study and Investigation of the Work, Activities, Personnel and Functions of Protective Reorganization Committees, Part III, Committees for the Holders of Real. Estate Bonds 225-28 (1936); id. Part VI, Trustees Under Indentures 143-50 (1936) (hereinafter SEC Trustee Report]; Senate Comm. on Banking and Currency, Trust Indenture. ACT of 1939: Report to Accompany S. 2065, S. Rep. No. 248, 76th Cong,, 1st Sess. 26 (1939) [hereinafter SENATE TRUST INDENTURE REPORT].

More recent evidence indicates that segments of the bond market would like terms that facilitate workouts. For example, bonds have been issued that conditionally allow the company to pay interest in new company stock instead of cash. See infra note 140. Complex exchange offers are structured to induce wide bondholder assent, see infra Section I-D, and general discussion in the bond market indicates demand for mechanisms that will bind all bondholders to facilitate a recapitalization.

21. 15 U.S.C. $\S \S 77 \mathrm{aaa}-77 \mathrm{bbbb}(1982)$.

22. See infra Section III. Since the Trust Indenture Act's prohibition has destroyed the clause for nearly a half-century, we cannot know whether companies would use the clause if it were permitted. Signalling effects, agency effects, tax frictions, and institutional regulatory requirements each pose obstacles to majority action clauses. Although best left for later discussion, I briefly note here that (1) the Bankruptcy Code now imposes majority action on creditors in bankruptcy, (2) the clause was occasionally used before its prohibition in 1939, despite some negotiability frictions, (3) similar corporate devices use majority votes in mergers to avoid holdout problems, (4) bond indentures in other countries with roughly similar legal and financial systems have used majority action clauses, and (5) preferred stock issues regularly have voting clauses for recapitalizations. These points are discussed infra text accompanying notes $72,64,114,138$ and 139 respectively. 


\section{B. A Brief Case Study of an Attempted Recapitalization: The Collapse of the MGF Oil Workout}

How seriously does the prohibition of bondholder votes impede nonbankruptcy resolution of a firm's financial troubles? The junk bond phenomenon is sufficiently new that we do not have detailed data on attempted junk bond workouts. The few years following the recent rise of the junk bond have been years of economic expansion, when issuer default is not widespread. ${ }^{23}$ We should expect more defaults in a future recession. ${ }^{24}$ Although the cause of most failed workouts is hard to discern, we can find a few nearly "pure" cases where the prohibition of majority action clauses made the difference between a successful pre-bankruptcy workout and bankruptcy.

MGF Oil Corporation explored for, developed and produced oil in the 1970 's, principally in west Texas and nearby states. As the price of oil soared in the 1970's, its business expanded. MGF financed much of its expansion with bank and other debt. In 1981 the company sold a large issue of junk bonds. In the early 1980's, the world price for oil fell and demand for drilling activity declined. Losing money, MGF stopped much of its drilling. ${ }^{25}$ However, the company had substantial preexisting obligations to creditors: It owed $\$ 150$ million to banks and $\$ 115$ million to junk bondholders. By mid-1984 MGF had liabilities of $\$ 295$ million while the company's value may well have been only $\$ 165$ million. ${ }^{26} \mathrm{MGF}$ was insolvent and headed for bankruptcy.

In August $1984 \mathrm{MGF}$ attempted to restructure, offering to exchange roughly two-thirds of its debt for new stock. The maturity of the remaining debt would be extended five years. ${ }^{27}$

The secured bank creditors conditioned their agreement to extend the maturity date, as well as to exchange one-quarter of their debt for stock, upon a minimum of $95 \%$ of the junk bondholders exchanging their bonds for stock. A high minimum tender condition is typical of the bond workout problem. When substantial risks of nonpayment to nonparticipating creditors are eliminated in a workout, the potential buoying-up effect is great. ${ }^{28}$ This effect can be minimized by a vote to bind all bondholders-which is prohibited - or by conditioning the restructuring on a large

23. Cf. Altman \& Nammacher, The Anatomy of the High Yield Debt Market: 1985 Update 2 (June 1986) (Morgan Stanley memorandum) (low default rate for junk bonds during 1980's).

24. Standard \& Poor's, Speculative Grade Debt: Credit Review 6 (June 15, 1987).

25. MGF OIL Corp., Exchange Offer Prospectus 34-35, 37 (Aug. 20, 1984) [hereinafter MGF Exchange OfFER Prospectus].

26. Id. at $12-13$.

27. Id.

28. The MGF scenario may be simplified if we posit a firm with operations worth $\$ 100$ million and a single bond issue worth $\$ 200$ million upon issuance. The debt is held in equal-sized portions by five creditors. If we ignore the hold-up value of stockholders, MGF would have this simplified balance sheet: 
majority of bondholders agreeing to the exchange. Eighty percent of MGF's bondholders tendered their bonds into the exchange offer. If MGF had a majority action clause, the workout might have succeeded; creditors concerned about buoyed-up holdouts would have been satisfied. ${ }^{20}$ But the offer failed and MGF filed for bankruptcy. ${ }^{30}$

\section{CHART 2}

MGF Balance Sheet 1

\begin{tabular}{l|l} 
MGF Balance Sheet 1 \\
\hline $100 \mathrm{M}$ & $\begin{array}{l}\text { \$100M Market value of debt } \\
\text { (\$200M face value) } \\
\$ \text { oM Common stock }\end{array}$
\end{tabular}

Each bond has a real value of $\$ 20$ million and a face value of $\$ 40$ million. Would four of the five bondholders agree to exchange their bonds for most or even all of the common stock? The residual bond, worth $\$ 20$ million before the exchange, would increase in real value to $\$ 40$ million after the exchange. Because the exchange would make a further workout unnecessary, the company could pay off the reduced level of debt to the remaining creditor according to her bond's terms. The holdout bondholder would gain at the expense of the four exchanging bondholders, who would lose $\$ 20$ million in the aggregate, having turned $\$ 80$ million of debt into $\$ 60$ million in stock $(\$ 100$ million in firm value, minus $\$ 40$ million in easily repayable, buoyed-up residual debt).

\section{CHART 3}

MGF Balance Sheet 2

$$
\$ 100 \mathrm{M}+\mathrm{Y}^{*}
$$

\$40M: Nonexchanging bondholder

$\mathrm{X}+\mathrm{Y}$ : Four exchanging bondholders

*(Y is the increase in MGF's operational value if the exchange offer succeeds. I have allocated all of $Y$ to the exchanging bondholders. In practice, the problem is more severe because shareholders would seek some of $\mathrm{Y}$ and could not be eliminated outside of bankruptcy.)

$\mathrm{X}$ cannot be worth more than $\$ 60$ million. Unless $\mathrm{Y}$ is sufficiently large, the buoying-up effect requires that all five bondholders go along. (Lest the reader think that $I$ have loaded the numbers with an extraordinary buoying-up effect, I will note that the actual MGF buoying-up effect was more severe. Prior to the exchange offer, the debentures were trading at 15 cents to 18 cents on the dollar. MGF Exchange OfFer Prospectus, supra note 25 , at I-4, J-4.).

29. Actually, even the MGF recapitalization is not a completely pure case. Although holders of MGF's major bond issues agreed to exchange by large $80 \%$ majorities that were nevertheless insufficient to get the deal done, one small bond issue, worth perhaps $10 \%$ of the company and apparently the holdout residual of an earlier exchange offer, held out entirely.

Why did so many of MGF's bondholders not hold out? One explanation may lie in the size of each holding. Because of the $95 \%$ participation minimum, anyone owning $5 \%$ or more of a bond issue lacked the ordinary buoying-up incentive to hold out, since by not tendering the large holder would have destroyed the deal. Another explanation is that some institutions and people simply do not act like the calculating prisoners in the dilemma.

The buoying-up problem cannot always be solved by increasing the threshold percentage of bondholders that must accept the exchange offer. By increasing that percentage, the firm will reduce the buoying-up problem: More bondholders will know that their refusal to tender will kill the deal. But a higher minimum also increases the chance that a single errant bondholder who thinks the deal is bad will prevent recapitalization. Similarly, the threshold percentage need not reflect the point at which buoying-up kills other creditor incentives to go along; the minimum percentage may be set strategically to affect enough holders' subjective assessment of whether holding out will thwart the deal. Scenarios could be constructed whereby a $60 \%$ threshold leads to widespread holding out, destroying the deal, but an $85 \%$ threshold induces sufficient tenders.

30. Several companies have attempted to recapitalize their bond issues before bankruptcy. See, e.g., Wahl, Exchange Offers: Old Versus New Securities, High Performance-The Magazine of High Yield Bonds 2, 4-5 (May 1986) (Morgan Stanley memorandum); Burrough \& Moffett, supra note 11, at 6, col. 1 (Crystal Oil "is counting on a last-ditch rescue" seeking to swap outstanding junk bonds for notes and stock.); Oxoco Inc. Again Extends Exchange of Debt Securities, Wall St. J., Sept. 13,1985 , at 42 , col. 6 (Unless $85 \%$ of debt securities agree to exchange offer, liquidation or chapter 11 filing would follow.); Tacoma Moves to Avoid Filing for Chapter 11, Wall St. J., July 18, 1985, 
MGF warned in its prospectus that if the offer failed, it would file for bankruptcy and expected to "present as its plan of reorganization a plan substantially identical to the restructuring plan set forth in this [Exchange Offer] Prospectus."31 MGF kept its word. ${ }^{32}$ Ironically, under the Bankruptcy Code a two-thirds majority of a creditor class can bind the entire group to the plan. ${ }^{33}$ Thus MGF filed for bankruptcy although in the attempted pre-bankruptcy workout it had the consents needed to file a binding plan covering its major bond issues had it been inside bankruptcy. ${ }^{34}$ Was the MGF bankruptcy necessary?

\section{Other Costs of Prohibition}

The inability to recapitalize smoothly-an inability sometimes exacerbated by the voting prohibition-imposes costs beyond those incurred by deadlocked bondholders involved in a heated, extended, and often unsuccessful recapitalization process. Economic resources can be misallocated. If attempts at workouts are unsuccessful, capital may not be made available for worthwhile projects, including the salvaging of ongoing projects, and rapid consolidation of a declining industry may be prevented.

We should shift our attention from MGF's attempted workout. That failure did not affect allocational efficiency because many other oil drilling firms had excess capacity. But if the failing firm is not in a perfectly competitive market or has unique opportunities, the firm's inability to raise new capital or merge carries substantial social costs beyond the transaction costs of recapitalizing. ${ }^{35}$

at 5, col. 3; Nazario, Sharon Steel Corp. May Have to Seek Aid in Chapter 11 Unless a Swap Is Approved, Wall St. J., May 14, 1985, at 12 col. 2.

Although not all recapitalization attempts fail, the questions are whether failures are common and whether the legal system reduces or increases the chances of failure. Despite a growing economy, twothirds of the dozen junk bond defaults in 1985 led to bankruptcy instead of successful workouts. Altman \& Nammacher, supra note 23, at 17.

31. MGF Exchange Offer Prospectus, supra note 25, at 9.

32. Disclosure Statement Accompanying First Amended Plan of Reorganization of MGF Oil Corp. at 1, In re MGF Oil Corp., No. 7-84-02160-E-11 (Bankr. W.D. Tex. filed June 11, 1985). But oil prices changed faster than reorganization plans could be proposed and acted upon; changing prices made it sensible for one claimant group or another to reject a plan proposed when oil prices were different. MGF and its claimants were, in the fall of 1987, considering yet another new plan of reorganization. Speedy recapitalization may be necessary to obtain bondholders' agreement before the acceptability to one claimant group or another of a proposed recapitalization is altered by economic change.

33. 11 U.S.C. $\S \S 1126(c), 1129(a)(8)(1982)$.

34. The Bankruptcy Code generally requires that, prior to solicitation of a vote, the court approve the solicitation documents as containing adequate information. 11 U.S.C. $\S 1125$ (b) (1982). Obviously, this effectively precludes use of the pre-bankruptcy consents. The rule is a carryover from the bankruptcy framework established in the 1930's, which mandates that no majority action outside of bankruptcy can bind dissenting bondholders without full judicial control of the recapitalization. See infra Section II-A-2. The rule is in theory, but apparently not in practice, now altered; prebankruptcy consents can be used but apparently only if there is no material change in the bankruptcy plan from the pre-bankruptcy plan, 11 U.S.C. \& 1126(b), presumably including no material change in the company's business which underlies the plan's results.

35. To see this point technically, let us change MGF, as shown in its balance sheet, supra note 
Even in fragmented, competitive industries, failed recapitalizations will impose costs. When industries decline, economic theory suggests that there often should be consolidation in the industry. ${ }^{36}$ The buoying-up effect will frustrate some worthwhile mergers. ${ }^{37}$

Chrysler's inability to recapitalize in 1979 and 1980-until it received government financing- might have nearly thwarted an arguably worthwhile project (the K-car) or merger. Chrysler's preexisting debt agreements, including $\$ 1$ billion in junk bonds, did not provide for the issuance of new, senior debt. The existing debt was so risky that providers of fresh money would have found themselves buoying up preexisting creditors (including the bondholders), unless the preexisting creditors agreed to alter the terms of their repayment. To attract new capital in a traditional financing, the K-car project had to provide not only an expected return greater than alternative uses of capital, but an expected return that, after the buoying-up return to preexisting creditors was subtracted, continued to be greater than the returns promised by alternative investments. ${ }^{38}$

28 , to a company that has declined in value but still has a good investment opportunity.

CHART 4

Balance Sheet 1

\begin{tabular}{l|l}
\hline $100 \mathrm{M}$ & $\begin{array}{l}\$ 100 \mathrm{M} \text { Market value of debt } \\
\text { (\$200M face value) } \\
\$ \text { OM Common stock }\end{array}$
\end{tabular}

Even a $\$ 100$ million common stock offering to exploit an opportunity expected to yield $\$ 150$ million would not be successful. Too much of the enhanced value would go to the bondholders. Some adjustment in the market value of the bonds would be needed to reflect the expectation that the bondholders would benefit from the corporate opportunity.

\section{GHART 5}

Balance Sheet 2

\begin{tabular}{l|l}
$\$ 250 \mathrm{M}$ & $\begin{array}{l}\$ 200 \mathrm{M} \text { market value of bonds } \\
\$ 50 \mathrm{M} \text { common stock }\end{array}$
\end{tabular}

36. E. MANSField, Microeconomics: Theory AND Applications 245, 252 (5th ed. 1985); see Higgins \& Schnall, Corporate Bankruptcy and Conglomerate Merger, 30 J. FIN. 93, 106-11 (1975). To be sure, industry decline should induce exit. But one firm could be strong in one productive aspect (say, distribution) and another strong in another aspect (say, processing of raw material); they should merge.

37. A strong acquirer will provide value to a distressed target's creditors who did not renegotiate the terms of their obligations during the merger. See Bulow \& Shoven, supra note 9, at 450-53. The purchaser of the firm, discussed supra note 35 , will find the first $\$ 100$ million of enhanced value going to the preexisting bondholders.

38. Chrysler's simplified 1980 balance sheet allows us to see this effect:

GHART 6

\begin{tabular}{l|l} 
Chrysler \\
\hline Book value & $\begin{array}{l}\$ 3.4 \text { billion bank, trade and } \\
\text { other debt } \\
\$ 1 \text { billion junk bonds } \\
\text { Common stock }\end{array}$
\end{tabular}

The bonds were trading at 34 cents on the dollar. Interest rates had increased after issuance, ac- 
Buoying-up and recapitalization deadlock were sufficient (although perhaps not necessary) to deter a possibly worthwhile project. ${ }^{39}$ Similarly, a merger might have created enhanced value for Chrysler's preexisting creditors, but have failed to create excess value that would accrue to the offering firm. ${ }^{40}$

Of course, when the buoying-up effect is small, or when previously negotiated covenants allow senior debt or a transactional alternative (such as separate incorporation for, or sale of, the new opportunity) deals can be worked out. But eventually these separation techniques can be exhausted;

counting for roughly one-quarter of the drop in the bonds' price. Accordingly, increased riskiness alone reduced the value of the bonds to around 50 cents on the dollar. With this figure, we can reconstruct a crude market-oriented balance sheet. Since the debt was not subject to intercreditor priorities, we can apply the crude $50 \%$ discount to all of the debt. A similarly rough market value of the common stock-presumably a result of its holdout value and the prospect of government funding-can be derived by multiplying the trading price by the shares outstanding.

CHART 7

\begin{tabular}{l|l} 
Chrysler \\
\hline$\$ 2.6$ billion & $\begin{array}{l}\$ 2.2 \text { billion debt ( } \$ 4.4 \text { billion } \\
\text { face) } \\
\$ 400 \text { million common stock }\end{array}$
\end{tabular}

Chrysler could have floated only new debt or equity that provided an unusually good return. Any operational project that promised a good risk-adjusted return on a $\$ 1$ billion inflow from a common stock offering had to have a value of at least $\$ 3.2$ billion to compensate for the buoying-up effect. Even though the firm had a positive stock price, large, billion-dollar capital inflows through a stock sale would have been prevented by the buoying-up effect. This result is counter to the intuition that if Chrysler had a project perceived as viable, i.e., having in itself a good return, financing would certainly have been available.

39. These factors need not have been the only explanation for Chrysler's difficulty in recapitalizing. Chrysler's position was so complex-and perhaps operationally untenable without informal import quotas-that even absent risky debt effects, the market still might not have viewed the investment as worthwhile.

40. See R. Reich \& J. Donahue, supra note 15, at 223 (Potential acquirers might "wait for Chrysler to disintegrate and then . . . pick up the best pieces without taking on its debt and pension liability.") (cmphasis added); id. at 239 (Ford rejects merger with Chrysler as "not being in the best interest of Ford or its stockholders") (footnote omitted) (emphasis added). Again, other reasons might explain a weakened merger market. Managers of Chrysler may have been reluctant to become managers of another firm's subsidiary. Managers of the firm into which Chrysler could have been merged might have been unwilling to undertake the risks to their reputations if Chrysler's operations failed.

In a similar example, Dome Petroleum has for several years had difficulty selling itself to a merger partner, apparently because of a lack of creditor unanimity in resolving the buoying-up effect. See MeNish, Some Dome Petroleum Lenders Oppose Sale of Concern and Prefer It Sell Assets, Wall St. J., June 19, 1986, at 4, col. 2; Bayless \& McNish, Dome Petroleum Weighs Sale of Firm In '87, Assuming Quick Action on Debt, Wall St. J., June 18, 1986, at 2, col. 2 (Conversion of bank debt to equity required before company can be sold.).

Poorly performing firms, like Chrysler and International Harvester in the late 1970's, are not often the target of a hostile takeover. See Coffee, Regulating the Market for Corporate Control: A Critical Assessment of the Tender Offer's Role in Corporate Governance, 84 ColuM. L. REv. 1145, 1203-04 (1984). The buoying-up effect might be one reason this is so. As performance slackens, preexisting debt becomes riskier. When potential acquirers find a target edging toward insolvency, they see a target whose creditors would be likely, through buoying-up, to take a good part of the benefit of any takeover. Accordingly, internal governance mechanisms may at this time be relatively more important than the hostile tender offer for the seriously troubled and insolvent firm. 
often they are barred by preexisting contractual arrangements, ${ }^{41}$ creditor protection statutes, ${ }^{42}$ antitrust rules, or managerial self-interest.

Firms in financial distress clearly do not always have worthwhile new opportunities. These troubled firms usually should be shrinking instead of expanding. But, when these firms do have good, even if only salvage opportunities, that require new cash, a merger, or the sale of most of their assets, they often cannot take advantage of them. Financial gridlock upsets allocational efficiency. When the lawyers' separation techniques are exhausted, the only remaining alternatives are renegotiation with preexisting creditors in a workout and bankruptcy.

\section{Reorganization Techniques that Reduce the Buoying-up Effect: Altering Holdouts' Incentives with Exit Consents and the Thin Residual Market}

Even when the separation techniques are exhausted, a recapitalization plan might be structured to reduce the buoying-up effect. Such plans usually must be attempted early during an operational decline to succeed. Three related courses of action are treated below: offering a security that is senior to (or more quickly maturing than) the target issue, requiring exchanging bondholders to vote to dilute indenture covenants on non-core terms just prior to the tender of their bonds, and noting the natural result

41. For example, preexisting creditors often will have insisted upon a negative pledge clause, which prohibits the firm from granting new creditors security without equally and ratably securing the preexisting creditors. In the absence of the negative pledge, the firm could change the expected risk of the loan by borrowing on a low-risk, low-cost secured basis, making the preexisting unsecured creditors worse off. Negative pledge clauses are common. See AMERICAN BAR Foundation, CoMmentaries on Model Indenture Debenture Provisions 350, 434 (1971); McDaniel, Bondholders and Corporate Governance, 41 Bus. LAw. 413, 427 (1986). Chrysler had negative pledge clauses in its loan agreements and bond indentures, and some say they nearly "wrecked the auto company's chances for survival." McDaniel, supra, at 427 (footnote omitted). Financial covenants regulating the amount of, or seniority of, new debt could also inhibit raising new capital via debt. AMERican Bar Foundation, supra, at 369-70.

Another ex post contractual obstacle is a clause, found in many bond indentures and loan agreements, requiring a company acquiring "substantially all" of the debtor's assets to assume the debtor's loans. Id. at 290-301. Cf. Bratton, The Interpretation of Contracts Governing Corporate Debt Relationships, 5 CARDOZO L. REv. 371, 384-85 (1984) (Clause is open-ended compromise between borrower who wants flexibility and lender who wants to limit changes in nature of the borrower's business.). To use the Chrysler example: Whether the K-car intangible asset and the tooling and parts in place by 1980 represented "substantially all" of Chrysler's assets would presumably have been a fair question for litigation; but there may have been little time to decide the matter. $C f$. Sharon Steel Corp. v. Chase Manhattan Bank, 691 F.2d 1039, 1048-49 (2d Cir. 1982) (construction of "substantially all" clause), cert. denied, 460 U.S. 1012 (1983). Prospective buyers of the K-car project would accordingly have been wary of how much debt they might simultaneously acquire. Once again, the only alternative would have been consent of the preexisting creditors, i.e., a workout.

42. For example, under fraudulent conveyance statutes, a creditor of an insolvent firm can attack some transfers of assets. See UNIFORM FRAuDuLENT ConveYANCE ACT \$§ 4-8, 7 U.L.A. 474, 504, $507,509,576$ (1985). A transfer from the insolvent firm to a new subsidiary or a third party could entitle the parent company's creditors to levy on the subsidiary or purchaser. If the transfer was for fair value, the parent company creditors could not attack the transfer, but prospective providers of fresh money to the new subsidiary or prospective buyers of the opportunity could easily be leery of the result of litigation on the fair value question. 
of a thin trading market for the nonexchanging bondholders. While each of these plans may diminish the buoying-up effect, none is assured of doing so and some raise fairness questions that have made them the subject of litigation.

\section{Senior Securities}

The firm can offer exchanging bondholders senior debt instead of common stock, thereby altering the target bondholders' calculus of value. ${ }^{43}$ The firm could also offer a mixture of stock and bonds, with the offered bonds maturing before the target bonds. The target bondholders would then have to assess the risk that cash will flow out of the firm to pay the more quickly maturing bonds and that the firm will later have difficulty repaying the remaining target bondholders. Distressed firm exchange offers often use these carrots and sticks.

How does seniority reduce the buoying-up effect? In the event of bankruptcy, the newly-created senior debt will be entitled to payment before the old debt. This loss of priority will make the expected value in bankruptcy of a holdout's claim less after the exchange than before the exchange. A prospective holdout will have to consider the chance of bankruptcy and a devalued claim before withholding her consent.

Ordinarily, for this type of exchange to relieve the company of stress, the exchanging bondholders have to give up current interest payments in return for some stock, deferred payment of interest, or another feature. However, these alternatives may not alter the buoying-up effect enough: In the interim between recapitalization and potential default, cash would flow out of the firm in interest and sinking fund payments to the nonexchanging bondholders. That is, if the new senior bondholders give up interest until a certain date, or defer sinking fund repayments, or exchange some of the principal of their bonds for stock, then some payments due to the nonexchanging bondholders will be better assured of payment, since the new seniors will have reduced some of the firm's competing cash requirements. A proposed exchange has pluses and minuses for all affected; it might not work.

Even if most of the bondholders exchange, an exchange for deferred senior debt often does not completely relieve the firm's financial stress. The firm still has a lot of debt to pay off; repayment has only been deferred. If the senior debt is risky, that riskiness may still impede raising new capital or merging, due to buoying-up of the senior debt. Also, the

43. Seniority is, to the extent relevant here, a creature of contract. Sometimes the target bonds allow issuance of senior debt through a subordination clause put in their indenture at the time of the bonds' issuance. Subordination can be created later by modifying the indenture after issuance. A subordination clause subjects the bonds to the risk that if the firm cannot pay creditors in full, the subordinated debt does not share ratably in the distribution, but waits until the designated senior debt is paid in full. 
firm may need the new senior's "place" in the capital structure to bring in a new creditor with fresh cash. Some exchanges to deferred senior debt, or to packages containing more quickly maturing debt, may occur only because the best recapitalization-to common stock or a different level of debt-cannot be readily implemented due to bargaining breakdowns. Seniority might not be permitted in the underlying documents; bondholders would have to be induced to amend their indenture to allow it. ${ }^{44}$

In sum, these techniques assure neither a completed recapitalization nor a financially viable firm even if the exchange offer is completed. They are often no more than second-best solutions.

\section{Exit Consents that Dilute Covenants}

Some bond indentures have protective covenants that limit the firm's ability to issue secured or senior debt. However, since the Trust Indenture Act $^{45}$ does not prohibit a vote modifying non-core covenants, bondholders may as a formal matter vote to change this covenant, allow the issuance of senior debt and bind the holdouts to the changed covenant.

A plan using an exit consent will require bondholders exiting through the exchange offer to consent, by a vote to modify the indenture, to remove the protective clause from the indenture. ${ }^{48}$ The exiting bondholders are bound by the vote only momentarily - until they give up their weakened bonds in exchange for the new consideration offered. The nonexiting bondholders, however, are bound. Under such conditions, bondholders may be induced to rush to tender bonds they might otherwise keep. Exit consents have become the subject of recent litigation, questioning the validity of a consent procedure that coerces the bondholders into an unwanted exchange. ${ }^{47}$

44. While I group use of seniority or a package containing more quickly maturing bonds in the same section with distorted transactions, use of senior or quickly maturing debt is not in itself a distortive mechanism if provided for in the target bondholders' indenture; the transaction is for the most part another separation technique. But if combined in a complex transaction with exit consents that create permission in the target indenture to allow issuance of senior bonds, whether to those exiting or to another target bond group, the transaction can be distortive. See infra Section I-D-2.

45. 15 U.S.C. $\$ \S 77$ aaa-77bbbb (1982).

46. E.g., Damson Onl Corp., Solicitation of Consents to Amendment of Indenture of 12\% Subordinated Debentures due 2003 (June 24, 1986); Pennzoll. Co., Offering Circular AND ConsEnt Solicitation (Aug. 14, 1986) (offering intended to eliminate restrictive covenants; company not on verge of bankruptcy); TEXas INTERnational Co., SOLICITATION OF ConsentS to AMENDMENT OF INDENTURE OF 13 1/8\% Senior Subordinated Notes due July 15, 1993 (June 25,1985 ) (exchange offer of stock for debt, with exit consents subordinating nonexchanging bondholders to another issue of bonds); Vermont Yankee Nuclear Power Corp., Offering Circular AND CONSENT Solicitation (Aug. 7, 1986).

47. Katz v. Oak Indus., 508 A.2d 873 (Del. Ch. 1986) (exit consent neither impermissibly coercive nor violative of redemption clause). Although the opinion did not explicitly discuss whether the Trust Indenture Act's standard of individualized consent was violated by the deal, the court implicitly rejected that view, stating that the deal was not impermissibly coercive. Id. at 879-81. See also GAF v. Union Carbide, 624 F. Supp. 1016, 1021, 1031-32 (S.D.N.Y. 1985) (dictum implicitly approving exit consents).

To date, lower courts have not stopped exit-consent exchange offers. An appellate court might rule 


\section{The Thin Residual Market}

Even in exchange offers without exit consents, an unavoidable element of coercion is present. A successful exchange offer will often leave less than $20 \%$ of a class of bonds outstanding, and financial analysts will stop following the bond issue. Trading becomes thinner, and the spread between bid and asked prices widens. If the bonds have a long maturity, their interim value may be severely diminished by this limited trading market.

\section{Effects on Individuals}

The costs of these techniques that deter holding out probably fall disproportionately on individual bondholders. Since institutions are more likely than individuals to react promptly to exchange offer papers, the affected bondholders may often be the few individuals left in the bond market, the very bondholders that the 1930's legislation was designed to protect. ${ }^{48}$

Allowing a binding bondholder majority vote to restructure the bonds' core terms would reduce the incentive to hold out. It also would reduce both the countervailing incentive to use distortive exit consents and the perception of unfairness that occurs when the few individuals remaining in the bond market misunderstand the consequences of failing to act upon an exchange.

that exit consents, if they devalue the target bonds, destroy the individual bondholder's freedom to choose to retain the original bond. The lack of a real choice, a future court may hold, so undermines the policy of individualized consent embodied in section 316(b) of the Trust Indenture Act, see infra Section II, that recapitalization by such consents, like recapitalizations by vote, must be prohibited. (And when such consents entail waiver of defaults, then, since section 316(a) prohibits the vote of the issuer, it might be questioned whether the bondholder is really voting in the shoes of the issuing company. This can be best imagined if the exchange offer conditions the payment of cash to the bondholder on the bondholder's waiver of defaults. Is the bondholder voting her own interest at that point, or is the bondholder indifferent, in effect the agent of the company that will momentarily reacquire the bond for the cash?) Such an appellate ruling could create acute efficiency questions because it would eliminate the current practical alternative to the prohibited vote and leave distressed firms paralyzed more frequently. Cf. Telephone interview with Messrs. Riff \& Kapes, Legal Staff of the California Commissioner of Corporations (Nov. 5, 1987) (Staff inclined to view such offers, if not exempt from registration with the commission, as inconsistent with state standard that offer be fair, just and equitable.).

The coercion, whether or not impermissible, arises in reaction to, or despite, the voting prohibition. Arguably, since section 316(b) mandates an individualized consent procedure, effectiveness of the mandate could require the prohibition of virtually all recapitalizations, a very unattractive result. If the section 316 (b) prohibition is not so broad, as practicality suggests it should not be, then, since it seems to induce use of distorted priority transactions or exit consents that bind nonexiting bondholders, the prohibition actually destroys elements of the individualized choice that it was intended to preserve. But the contribution of the exit-consent/exchange offer to American corporate finance should not be underestimated. The exchange appears to be more complex than the vote, thus better justifying a hefty investment banking fee.

48. See infra Section II. 


\section{Summarizing the Mixed Incentives}

In sum, bargaining frictions in a multi-creditor recapitalization are substantial; differences of opinion, mistrust, and strategic action may inhibit agreement, and buoying-up makes the nonagreement of any significant number of creditors potentially devastating.

In reaction to, or despite, the voting prohibition enacted to protect individual bondholders, clever reorganization techniques have been developed that change bondholder incentives by damaging bondholders if they hold out. But these techniques are incomplete as a solution to the recapitalization problem for two substantial reasons. First, there is no assurance that they will be regularly effective. For example, to induce bondholder consent because of fear that the restructured indenture will be stripped of viable covenants, there first must be significant financial covenants to strip away. Many original issue junk bonds have no such covenants to delete. Alternatively, the restructuring may induce consent but be ineffective because the exit consent works only if debt is used in exchange. A firm will often prefer a recapitalization in which creditors become stockholders or further stretch out their maturity; creditors might have agreed to such a stretch-out or exchange if a vote reduced the number of holdouts. Second, the consent procedure is an incomplete solution because it raises fairness considerations that courts or regulators might act upon. Individual bondholders seem those most likely to be hurt. While initial litigation has not stopped exit-consent transactions, questions have been raised whether the process violates the bond indenture.

Whether a vote would facilitate smoother recapitalization and actually be fairer than the current process deserves examination. In the next Section, I critically examine the persuasiveness of the original bases for the half-century-old prohibition.

\section{The Prohibition of Majority Action Clauses by the TRUST INDENTURE ACT OF 1939}

Prior to the public issuance of most bonds, the governing bond indenture must be qualified under the Trust Indenture Act of 1939, which prohibits the use of an indenture that allows modification by majority action of any core term of the bond:

The indenture to be qualified shall provide that, notwithstanding any other provision thereof, the right of any holder of any indenture security to receive payment of the principal of and interest on such indenture security, on or after the respective due dates expressed in such indenture security . . . shall not be impaired or affected without the consent of such holder. ${ }^{48}$

49. Trust Indenture Act of $1939 \S 316(\mathrm{~b}), 15$ U.S.C. $\S 77$ ppp (1982). 
Why did Congress enact this prohibition? Although the Trust Indenture Act's legislative history is sparse, the Securities and Exchange Commission's approximately 5000-page study of corporate reorganization, which provided the impetus for the Act, ${ }^{50}$ is not. Begun pursuant to the Securities and Exchange Act in 1934 under William O. Douglas' tutelage and completed in 1939, this study reflected the SEC's fear of insider control of bond issues and its concern about the poor quality of information that flowed to bondholders.

A consistent theme emerges from the SEC study of trust indentures, Douglas' congressional testimony, and Douglas' later Supreme Court corporate reorganization opinions: Only two events should change a company's obligation to pay its bonds. Either each affected bondholder would consent to the alteration of the bond's terms, or a judge would value the company to determine that the firm was insolvent, eliminate the stockholders, and then reduce the express obligation to the bondholders. Congress and the SEC were aware that the holdout problem would frustrate some workouts, ${ }^{81}$ but the regulators wanted to impede workouts that took place outside of regulatory and judicial control. The SEG wanted trust indenture legislation that would bring contractual recapitalizations under the jurisdiction of the federal bankruptcy court. ${ }^{52}$

\section{A. Why Did Douglas Want Majority Action Clauses Prohibited?}

\section{Insiders, Quasi-insiders, and Poor Information}

Douglas' desire to prohibit majority action clauses was partly prompted by a fear that insiders could gain control of a bond issue and destroy it for the insiders' benefit. What the insiders lost by forgoing interest or principal payments, they recouped as stockholders. What the outsiders lost as bondholders, the insiders gained as stockholders. As long as the insiders owned a greater percentage of the stock than of the bonds, forgiveness of bond repayment would be profitable for them.

50. See id. $\S 302(a), 15$ U.S.C. $\$ 77 \mathrm{bbb}(1982)$; SENATE TRUST INDENTURE RePORT, supra note 20, at 32; House Comm. on InTERstate and Foreign Commerce, Trust Indenture Bill of 1939, H.R. REP. No. 1016, 76th Cong., 1st Sess. 35 (1939).

51. See supra note 20 and infra note 55.

52. See, e.g., SEC, Report ON THE StUdy and Investigation of the Work, Activities, Personnel and Functions of Protective and Reorganization Committees, Part I, Strategy and Technigues of Protective and Reorganization Committees 870-71 (1938) [hereinafter SEC Strategy Report]; id. Part VIII, A Summary of the Law Pertaining to Equity and BankRUptcy Reorganizations and of THE Commission's Conclusions and RECommendations, at 100-01 (1940) [hereinafter SEC REORganization RePORT].

Douglas asserted that since courts accept approval by a large percentage of creditors as an indication of fairness, legislation should prohibit the solicitation of consents to a plan until after the court has approved it, thus freeing the court to use its power and judgment in favor of investors. W. DougLAS, The Need for Reform in Corporate Reorganizations, in DEMOCRACY AND FinanCE 189-90 (J. Allen ed. 1940) (edited version of 1937 Douglas speech). See also Frank, Some Realistic Reflections on Some Aspects of Corporate Reorganization, 19 VA. L. REv. 541, 568-69 (1933) (Jerome Frank, later chairman of SEC, arguing for active court supervision of reorganization plans). 
The SEC believed insider destruction of bond issues was common. There were, in fact, attempts at insider control, ${ }^{53}$ and, although the reported attempts were unsuccessful, the issue was a subject of much discussion. ${ }^{54}$ The SEC Protective Committee Report discussed several insider efforts at bond control and destruction. ${ }^{65}$ The Report also stated that investment banks often became the moving force in organizing and controlling the bondholders' committees. The investment bank might have owned only a few of the bonds, but hoped to do future business with the company if the reorganization was successful. The prospect of future underwriting fees induced laxity in pursuing bondholders' interests. ${ }^{56}$ According to the SEC Report, the minority of bondholders who feared the passivity or collusion of quasi-insiders were denied effective remedy when the quasi-insiders gained control of enough bonds to be able to compromise the entire bond issue. ${ }^{.7}$

The SEC also believed that dispersed individual bondholders received poor information about the company's prospects or received information that they could not skillfully evaluate and then gave ill-advised consents. ${ }^{58}$ The misinformed, together with the insiders and quasi-insiders, could bind all bondholders to the recapitalization.

53. In Hackettstown Nat'l Bank v. D.G. Yuengling Brewing Co., 74 F. 110 (2d Cir. 1896), for example, insiders attempted to destroy a bond issue but were defeated by a judicial holding that a majority vote to change a bond's terms had to be given in good faith. Cf. Aladdin Hotel Co. v. Bloom, 200 F.2d 627 (8th Cir. 1953) (In pre-Trust Indenture Act indenture, insiders acquire bonds and vote to extend maturity.).

54. The Hackettstown case figured in prominent legal corporate finance texts of the 1930's. See, e.g., A. Berle, Cases and Materials on Corporate Finance 556 (1930); W. Douglas \& C. Shanks, Gases and Materials on the Law of Financing of Business Units 205, 271 (1931). See also Douglas, Protective Committees in Railroad Reorganizations, 47 HARv. L. REv. 565, 567 (1934) ("So often [protective] committees have been constituted by the inside groups, those affiliated with . . management.").

55. SEG, Report on the Study and Investigation of the Work, Activities, Personnel and Functions of Protective and Reorganization Committees, Part II-Committees AND Conflicts of INTERest 162-63 (1937) [hereinafter SEC CoMmitTEE Conflicts RePORT); see also id. Part VII: Management Plans Without Aid of Committees, at 438-61 (1938) [hereinafter SEC MANAgement Plan Report; SEC Reorganization RePoRT, supra note 52, at 113-61.

56. SEC Commitree Conflicts RePoRT, supra note 55, at 13, 159, 171-72; W. Douglas, supra note 52, at 187-88, 205; see also Regulation of Sale of Securities: Hearing on S. 2344 Before a Subcomm. of the Senate Comm. on Banking and Currency, 75th Cong., 1st Sess. 17, 28 (1937) [hereinafter Senate Hearings I] (statement of William O. Douglas, member of SEC) ("[The underwriter] conceal[s] defaults until the reorganization stage is set, in order to obtain for itself the many emoluments that run to those who are able to control reorganizations.").

57. In the 1980's version of this conflict-of-interest problem, the indenture trustee is often a commercial bank lender to the debtor. While the bank resigns as trustee when a recapitalization is attempted, litigation often raises the question whether the trustee would have acted more quickly on behalf of the debenture holders were it not also a lender. See In re W.T. Grant Co., 699 F.2d 599 (2d Cir. 1983); V. Brudney \& M. Chirelstein, Corporate Finance 99 (2d ed. 1979); Friedman, Updating the Trust Indenture Act, 7 Mich. J.L. ReForm 329 (1974).

58. SEC COMmTtTeE Conflicts REPORT, supra note 55, at 1 . See also Senate Hearings I, supra note 56, at 32 (comments of Sen. McAdoo) ("[T] he average [individual] cannot . . . understand the technical terms."); W. Douglas, Protective Committees, in Democracy and Finance, supra note 52 , at $197,198-99$. 


\section{The Corporate Reorganization Framework Completed:}

Los Angeles Lumber Products

In the context of the Great Depression and the New Deal, the regulatory alternative chosen by the SEC and Douglas-forced judicial scrutiny of recapitalization plans in place of market-based contractual alterations-must have seemed especially sensible. Also, ancillary regulation concerning negotiability made the framework a confirmation of existing practice, ${ }^{58}$ and the economic groups likely to oppose the framework were politically weakened during the Depression. It is thus possible that neither the regulators nor their opponents carefully scrutinized whether the prohibition of majority votes made sense for bondholder recapitalizations.

Bondholders voted by large majorities to recapitalize in several reorganizations in the 1920's and 1930's. The troubled firms, apparently unable to confirm the recapitalization under the existing interpretation of the $\mathrm{Ne}$ gotiable Instruments Law (N.I.L.) or other regulation, ${ }^{60}$ would file for bankruptcy. ${ }^{61}$ Until Douglas restructured bankruptcy reorganizations later in the 1930's, bankruptcy courts deferred to parties consenting to a recapitalization plan by prior majority vote.

By 1939, with his celebrated opinion in Case v. Los Angeles Lumber Products Co. ${ }^{62}$ Douglas' complete reorganization system for public companies was firmly in place. In Los Angeles Lumber Products, Douglas interpreted the statutory standard-that a plan be "fair and equitable"-to require that every affected creditor must consent to deviation from absolute priority. The only alternative was a judicial valuation hearing to determine the extent of the firm's insolvency and to eliminate the stockholders. ${ }^{\text {Bs }}$ Douglas was unconcerned that the bankrupt's bond indenture explicitly allowed modification of the bonds' core terms by a three-

59. See infra Section II-A-3.

60. See infra Section II-A-3 for discussion of the role of the Uniform Negotiable Instruments Law. A proceeding was often necessary to bind absent creditors. See, e.g., Northern Pacific Ry. v. Boyd, 228 U.S. 482, 509-10 (1912). This absentee problem arguably differed from bondholders binding themselves under a majority action clause, but presumably in many recapitalizations both problems were present. See infra note 68.

61. SEC STRATEGY REPORT, supra note 52, at 317 (Reorganization fails although $90 \%$ of bondholders assent; cash payout to dissenters would be too great.); id. at 320 (Mr. Swaine, reorganization attorney, stating: "I never believed we could get [sufficient] voluntary assents . . . [to recapitalize] without doing something to bind the minority."); id. at 871 (same); SEC Management PLAN REPORT, supra note 55, at 355 n.11 (Allegheny Corp.'s reorganization).

62. 308 U.S. 106 (1939). Los Angeles Lumber Products is central to corporate reorganization doctrine. See, e.g., RePORT of THE Commission on THE BANKRUPTCY LAWS OF THE UNITED States, H.R. Doc. No. 137, PT. I, 93d Cong., 1st Sess. 255 (1973); D. Baird \& T. Jackson, Cases, Problems, and Materials on Bankruptcy 608, 615 (1985); W. Blum \& S. Kaplan, Corporate Readjustments and Reorganizations 357 (1976); Dodd, The Los Angeles Lumber Products Case and Its Implications, 53 HARv. L. REv. 713 (1940).

63. Case v. Los Angeles Lumber Prods., 308 U.S. 106 (1939) (Douglas, J.); Consolidated Rock Prods. v. DuBois, 312 U.S. 510 (1941) (Douglas, J.) (Juniors could receive same type of securities as seniors as long as seniors were fully compensated.). 
fourths vote, ${ }^{64}$ which might have allowed him to think of the bondholders as a single creditor, such as a single lending partnership that agreed internally to the procedures used to approve any renegotiation of the partnership's loan to the firm.

Careful examination of the facts reveals the perniciousness of the holdout problem and the buoying-up effect. ${ }^{65}$ Los Angeles Lumber Products' principal business was shipbuilding. The company desperately needed new funds to expand its shipyard to build ships under government construction contracts, ${ }^{68}$ but potential buoying-up of its preexisting creditors washed it out of the market for new capital. ${ }^{67}$ The company then sought an all-equity capital structure with the final plan according the bondholders $77 \%$ of the firm's stock. More than $80 \%$ of the bondholders approved the plan, but, apparently because of doubts about whether the clause would bind dissenters outside of bankruptcy, the company sought a binding bankruptcy confirmation. The lower court thought the contractual permission for a binding super-majority vote was sensible: "All of us know from sad experience that one or two recalcitrant bondholders were able . . . to hold up very definitely beneficial plans until they were paid off 100 cents on the dollar."'88

Twenty percent of the bondholders, with about $\$ 760,000$ principal

64. In re Los Angeles Lumber Prods., 24 F. Supp. 501, 504 (S.D. Cal. 1938), affd, 100 F.2d 963 (9th Cir.), rev'd sub nom. Case v. Los Angeles Lumber Prods., 308 U.S. 106 (1939).

65. The frustrated recapitalization of Los Angeles Lumber Products reflected the same difficulties encountered by Chrysler and MGF. Like Chrysler, Los Angeles Lumber Products could not get new capital for its operations because it was already too debt-heavy. Like MGF, it could not recapitalize because of holdouts. The Trust Indenture Act prohibited MGF from seeking a contract allowing a bondholder vote outside bankruptcy; Douglas' Supreme Court opinion prohibited Los Angeles Lumber Products from using a bondholder vote inside bankruptcy.

66. 24 F. Supp. at 505-06.

67. Id. at 505 (debtor unable to secure credit, "due to debtor's top-heary bond structure, nor (was it] . . able to secure faithful performance bonds which were essential to the undertaking of any shipbuilding contracts") (emphasis added).

68. Id. at 509. The lower court concluded that it would not approve a bankruptcy plan that was unfair and inequitable, but that overwhelming class consent was strong evidence that the plan was fair and equitable. Id. at 513-14.

Why was a bankruptcy filing necessary if the bond indenture-a pre-Trust Indenture Act indenture-had a majority action clause and the reorganization affected only bondholders? The company originally proposed that the plan be confirmed under the contract's majority action clause or under Section 77B of the then-in-force Bankruptcy Act. 308 U.S. at 110. The opinions do not discuss why the company needed a bankruptcy confirmation, but the need may have stemmed from negotiability problems.

Some courts' interpretations of the N.I.L. allowed a nonassenting bondholder to sue on the bond's payment terms (but not under the separate indenture), if the bond were in the proper form of a negotiable instrument, notwithstanding any majority action under the indenture. See Crocker Nat'l Bank v. Byrne \& McDonnell, 178 Cal. 329, 173 P. 752 (1918); infra Section II-A-3. If there were enough holdouts, prudence demanded that the company seek confirmation of the plan under the Bankruptcy Act, a common practice at the time. See sources cited supra note 20 . The bankruptcy confirmation, denied by the Supreme Court, would have bound those holdouts notwithstanding state standards of negotiability. Alternatively, the company might have interpreted Northern Pacific Ry. $v$. Boyd, 228 U.S. 482 (1913), to require bankruptcy confirmation of plans affecting nonassenting creditors, despite the fact that the creditor in Boyd was not bound under a majority action indenture. (Despite the dissimilarity, Boyd was cited to support the Los Angeles Lumber Products result. 308 U.S. at 115.) 
amount of bonds, dissented from the out-of-bankruptcy recapitalization. Since the company was valued at $\$ 900,000,{ }^{69}$ the buoying-up effect was enormous. This fact went unnoticed, or at least undiscussed, by the court and others since. The holdouts would have taken most of the company.70 Like MGF a half-century later, Los Angeles Lumber Products was forced into bankruptcy.

Douglas, speaking for the Court, would not allow the contractual majority clause to rule in bankruptcy. A bondholder, he held, could be fairly and equitably bound only by her own consent or by a valuation hearing that eliminated the junior interests in the firm to the extent needed to assure bondholder compensation. For the next forty years Douglas' bankruptcy reorganization framework governed bankruptcy reorganizations of public companies. ${ }^{71}$

Congress destroyed the bankruptcy half of the framework in 1978. Under the Bankruptcy Reform Act of 1978, the judge has no authority to intervene if the affected creditors agree to the plan by a two-thirds vote. The judge determines whether the plan compromises the creditors' claim only if the creditor class votes against the plan. ${ }^{72}$ Since the principal impetus behind the Trust Indenture Act's prohibition was to require judicial scrutiny in bankruptcy of a recapitalization plan, ${ }^{73}$ the prohibition's raison d'etre is now gone.

69. 308 U.S. at 119.

70. The binding of holdouts might not have been the only problem in the Los Angeles Lumber Products reorganization. Even the assenting bondholders might not have been bound outside of bankruptcy. If the solicitation did not call attention to the fact that holdouts would not be bound, perhaps in an effort to minimize the number of holdouts, the assentors might have been able to sue on their bond or under a fraud claim. Alternatively, an assentor might negotiate his bond to a third party, who as a holder-in-due-course could sue the company on the bond. If there were only a few holdouts, the company might have lived with the ambiguities under the contract, or bought a few thousand dollars worth of holdouts' bonds. But when the company saw that the holdout group, although only $20 \%$, was large enough to take most of the company's value and that even the assenting majority might unravel, it declared bankruptcy.

71. Although originally not intended for use by public companies, chapter XI of the old Bankruptcy Act provided a voting assent mechanism similar to the current chapter 11, enacted in 1978 . Its assent mechanism proved sufficiently desirable to some reorganization actors that they maneuvered bankrupts into chapter XI.

72. 11 U.S.C. $\S \S 1126(c), 1129(a)(8)(A), 1129(b)(1)(1982)$. The new Code explicitly uses Douglas' fair and equitable standard only as an alternative to consent if two-thirds consent is not forthcoming. The Code thus establishes a framework of judicial passivity in consent matters, making the judge little more than a vote recorder. Judges are even prohibited from attending crucial meetings of creditors. Id. $\S 341$ (c). See also Dunham \& Borowitz, supra note 14, at 443-44 (Lawyers advise indenture trustees not to rely on court's or trustee's assessment of debentureholders' claims.). Individualized consent is required only if the plan would give an impaired class less than the liquidation value of its claim. Id. $\S 1129(\mathrm{a})(7)(\mathrm{A})$.

The judge's only significant control over the modern-day proceeding derives from control over the papers used to obtain the consents. Id. $\S 1125$ (b) (Solicitation statements must contain adequate information as approved by judge.). However, this control is also weak, involving limited scrutiny. See infra note 93 .

73. "Evasion of judicial scrutiny of the fairness of debt-readjustment plans is [intended to be] prevented by this [section 316(b)] prohibition." SENATE TRUST INDENTURE REPORT, supra note 20, at 26. See also supra note 52 (indications by Jerome Frank and William Douglas that bankruptcy was desired). 
The interplay between the new Code's voting structure and the voting prohibition outside of bankruptcy is startling. Douglas would not enforce an indenture's voting clause in bankruptcy; yet under the new Code a bankruptcy judge will not enforce an indenture's voting prohibition. Bondholder recapitalizations are caught in a destructive cycle of regulation: In a bankruptcy the new Bankruptcy Code destroys contractual arrangements that legislation nearly fifty years old forces the parties to use. Some firms resort to bankruptcy partly because of the very legislation that bankruptcy overrides.

\section{How Carefully Did Congress Investigate Douglas' Perspective Before Adopting the Prohibition?}

Although Congress heard criticism of the majority action prohibition, inquiry was shallow and controversy limited. The prohibition only confirmed existing ancillary regulation. The SEC testified that $90 \%$ of the indentures it examined prohibited majority action. ${ }^{74}$ Moreover, the wisdom of the times suggested that regulation and reorganization in bankruptcy would be cheap, expert, and easy.

The prevailing interpretation of negotiability requirements had already led to disuse of majority action clauses. To be negotiable under the 1930's N.I.L., the bond had, inter alia, to "contain an unconditional promise .. . to pay a sum certain in money . . . [and] be payable . . . at a fixed or determinable future time."'75 If the bonds' principal amount could be reduced, or their maturity extended, by majority vote, a minority bondholder's bond might not meet that statutory standard.

Indeed, majority clauses seemed to fail tests of negotiability. Treatises from the early part of the 20 th century stated as much. ${ }^{76}$ Some old cases were more explicit, ${ }^{77}$ and a leading case tended to confirm then-current fears that an effective majority action clause could not coexist with negotiability. In Enoch v. Brandon, ${ }^{78}$ the New York courts viewed the bond

74. House Hearings I, supra note 20, at 237, 284 (statement of Edmund Burke, Jr., Assistant Director, Reorganization Division of SEC).

75. UNIF. Negotiable InStRUments Law § 1(2)-(3) (1896); see King Cattle Co. v. Joseph, 158 Minn. 481, 490, 199 N.W. 437, 438 (1924) (custom and usage cannot make bond negotiable; conformity to N.I.L. is necessary); Note, The Applicability of the N.I.L. to Bonds, 25 CoLUM. L. REV. 71, $72-73$ (1925).

76. See, e.g., L. Jones, A Treatise on the Law of Bonds and Mortgages $\S 191$, at 214 (3d ed. 1907).

77. See, e.g., Crocker Nat'l Bank v. Byrne \& McDonnell, 178 Cal. 329, 332, 173 P. 752,754 (1918) (decided under California Civil Code); McClelland v. Norfolk S. R.R., 110 N.X. 469, 476, 18 N.E. 237, 240 (1888) (pre-N.I.L. case).

78. 128 Misc. 695, 697, 220 N.Y.S. 294, 296 (1927) (Express sum-certain terms of bond dominate majority action clause of ancillary indenture; only for that reason was bond held negotiable.), affd, 249 N.Y. 263, 164 N.E. 45 (1928). See R. STEFFEN, Cases on Commercial and InvestMENT PAPER 267-71 (1939); Billyou, Corporate Mortgage Bonds and Majority Clauses, 57 YALE L.J. 595, 600 (1948); Steffen \& Russell, The Negotiability of Corporate Bonds, 41 Yal. L.J. 799, 807 (1932). 
and the indenture as separate instruments providing cumulative rights. A bondholder took the short obligation, the bond with its crisp promise to pay by a date certain, and took additional rights under an indenture. ${ }^{79}$ If the bond were taken subject to the indenture, then the indenture's impingement of the bond's sum-certain, date-certain terms would destroy the negotiability of the bond. ${ }^{80}$ The Enoch case led prominent commentators to doubt the negotiability of bonds with effective majority action clauses. ${ }^{81}$

While the lack of an effective majority action clause could make a future workout difficult, that defect was insignificant when compared to the constricted marketability and liquidity of non-negotiable bonds. Competent counsel, recognizing that the majority action clause either was unenforceable or would destroy negotiability, generally omitted the clause from the bond indenture. Ancillary regulation of the legal investments of insurance companies and savings banks had a similar effect. ${ }^{\mathbf{2 2}}$

Negotiability and its derivative restraints may have led Congress and

79. The bond obligated repayment on the maturity date and promised interim interest. The indenture provided financial covenants, making it an event of default to incur certain levels of debt, to pledge assets to other creditors, or to fail to maintain security at an adequate level.

80. See Hibbs v. Brown, 190 N.Y. 167, 172-73, 82 N.E. 1108, 1109-10 (1907) (Bond indenture's majority action clause controls only collective foreclosure and acceleration actions arising from financial covenant defaults; holder could individually sue on bond and coupon for payment defaults irrespective of any majority action under indenture.); Pflueger v. Broadway Trust \& Sav. Bank, 351 III. 170, 176-77, 184 N.E. 318, 321 (1933); Guardian Depositors Corp. v. David Stott Flour Mills, 291 Mich. 180, 289 N.W. 122 (1939).

At odds with, and in different jurisdictions than, Enoch were a few decisions interpreting no-action clauses, under which only the trustee or a specified minimum number of bondholders could sue. Some courts held the indenture clause to bind the bondholder, limiting rights under the bond. See, e.g., Allan v. Moline Plow Co., 14 F.2d 912 (8th Cir. 1926). Most courts, particularly those in New York, reconciled the indenture's no-action clause with the bond's negotiability similarly to Enoch: The noaction clause only limited rights under the indenture (e.g., rights to foreclose on the mortgage, acceleration rights), and did not affect the payment promises made in the bond. See, e.g., Cunningham v. Pressed Steel Car Co., 238 A.D. 624, 265 N.Y.S. 256 (1933), affd per curiam, 263 N.Y. 671,189 N.E. 750 (1934). See generally R. MCClelland \& F. Fisher, The Law of Corporate MorTGAGE BOND Issues 136, 139-40, 144-49 (1937) (discussing Enoch and its progeny).

Although the indenture's no-action clause usually deprived individual bondholders of rights only under the indenture, the majority, by denying indenture foreclosure and acceleration rights, in a manner similar to the two tiers of exit consents, discussed supra Section I-D, could sometimes use the clause to force reluctant holdouts to come to terms.

Douglas apparently was concerned about such use. See supra note 52. The Trust Indenture Act is partly a reaction to that use.

81. Swaine, Reorganization of Corporations: Certain Developments of the Last Decade, 27 Colum. L. Rev. 901, 927 (1927). See also Billyou, supra note 78, at 599-601; Steffen \& Russell, supra note 78 , at 814,826 .

82. Regulators of insurance companies and savings banks impose limits and restrictions on the investments that banks and insurance companies may make. In the 1920's and 1930's, regulators promulgated "legal lists" that prohibited investment in bonds with majority action clauses, apparently to keep their wards' bonds negotiable. Israels, Investment Securities in New York: Statutory Text and Commercial Practice, 48 CoRnell L.Q. 108, 112 (1962); see Trust Indenture Act: Hearings on S. 477 Before a Subcomm. of the Senate Comm. on Banking and Currency, 76th Cong., 1st Sess. 30 (1939). The New York Stock Exchange refused to list bonds allowing majority action modification of the core indenture terms. At least at first, the Exchange rule was redundant of the negotiability issue: Wishing to assure negotiability of listed bonds, the Exchange prohibited the clause's use. Billyou, supra note 78, at 597; Stetson, Preparation of Corporate Bonds, Mortgages, Collateral Trusts and Debenture Indentures, in CoRporate Financing, supra note 20, at 1, 72. 
those who favored majority action clauses to be unconcerned with the Trust Indenture Act's prohibition. The prohibition only reinforced the existing state of affairs. Subsequently, however, the other restrictions were lifted. The Uniform Commercial Code (U.C.C.) was promulgated in 1952 and has been enacted in forty-nine states. Unlike the sum-certain, datecertain standards imposed for checks and commercial paper under Article 3 of the U.C.G. and for bonds under the defunct N.I.L., Article 8 of the U.G.C., which governs bonds, defers to custom as the standard for determining the negotiability of bonds. ${ }^{83}$ The old requirement that destroyed the negotiability of majority-action bonds is gone, but no court has definitively decided the issue of the bonds' negotiability because the Trust Indenture Act has banned majority action clauses in publicly-issued corporate debt during Article 8's existence. ${ }^{84}$

The result is a peculiar regulatory history. Prior to the Trust Indenture Act ban, the Negotiable Instruments Law rendered the majority-action clause useless or harmful. Opposition to the impending federal prohibition was accordingly weak. But subsequent change dissolved the negotiability considerations that had made the prohibition standard. The 1930's Trust Indenture Act no longer merely confirms the results of practice.

\section{B. Are Douglas' Fears Valid in the 1980's?}

The financial world has changed in the half-century since the enactment of the Trust Indenture Act. Individuals hold fewer bonds directly today than regulators thought they held in the 1930's. For many public companies, direct insider control of a bond issue is unlikely. Widelydispersed common stock further weakens the prospect of some forms of insider control. Most importantly, the nature of institutional intermediaries in the 1980's lessens and perhaps eliminates the chance that unsophisticated bondholders will be cheated in the manner feared in the 1930's. Lastly, the pace and magnitude of economic dislocations in the 1980 's make it important that workouts be facilitated. Even so, the chief concern of the 1930's legislation-protection of the individual bondholder -merits examination. New reasons to fear bondholder mulcting arise with the new intermediaries-but I suggest in this Section that the voting prohibition is ill-suited to protect bondholders in the 1980's.

83. Article 8 provides that "certificated securities" are negotiable. U.C.C. \$ 8-105 (1977). Certificated securities are defined as participations in an enterprise, if commonly traded on a stock exchange as an investment vehicle. Id. $\$ 8-102(1)(a)$.

84. Similarly, the legal investment restrictions for savings banks and insurance companies have eased since the 1930's. For example, in 1984 New York amended its previously restrictive legislation; the existence of a majority action clause is now irrelevant to whether the investment is permitted. N.Y. Banking LAw $\S 235$, subd. 30 (McKinney Supp. 1987); N.Y. INS. LAw $\S \S 1402,1403,1405$ (McKinney 1985). Similarly, the stock exchange rules no longer directly prohibit listing for trading of bonds with majority action clauses. N.Y. STock Exchange, CompanY Manual § A5 (1981). 


\section{The Rise of the Institutional Intermediary}

Few individuals in America today own corporate bonds directly. Instead they own interests in pension funds or mutual funds, including junk bond mutual funds. Ninety percent of the bond market-and reportedly $95 \%$ of the junk bond market-is institutional. ${ }^{85}$

The institutional intermediary suffers from fewer disabilities than the individual in a junk bond workout. Institutions are better able to detect a corrupt deal. They can better assess the value of the bonds if the proposed recapitalization fails, the value of the company as a whole, and hence the advantages and disadvantages of the proposed recapitalization. Finally, since the intermediary, unlike the individual, often holds its bonds in million-dollar lots, its scrutiny of a proposed plan for recapitalization will be more searching than that of the individual. ${ }^{88}$

The institutional intermediary's staff is also more skilled than the individual at analyzing a recapitalization and gathering information to evaluate independently the issuer's proposal. ${ }^{87}$ Given the extent of institutions'

85. Board of Governors of the Federal Reserve System, Flow of Funds Accounts, Financial Assets and Liabilities, Year-End, 1961 -1984 36, lines 8-9 (1985) [hereinafter Federal Reserve Financial. Holding Datal (bondbuyers more than $90 \%$ institutional). See generally Wall Street Week: In Defense of Junk Bonds (PBS television broadcast, Apr. 18, 1986) (transcript available from PBS) (interview with James Balog, Vice Chairman, Drexel Burnham Lambert, Inc., leading underwriter of junk bonds); House Junk Bond Hearings, supra note 2, at 59-60; Monroe, Metromedia Unit Issues \$1.9 Billion of 'Junk Bonds'; Offering Called Largest, Wall St. J., Nov. 30,1984, at 48, col. 2 (issue sold entirely to institutional investors).

86. If the cost of evaluation were especially large, institutional free riding would be detrimental to the bondholders. That is, if, for example, a \$500,000 investment in information were necessary before a holder of $\$ 5$ million of bonds (out of a $\$ 100$ million issue) could sensibly decide whether to assent to a capitalization proposal, then rational apathy would lead to no vote, a random vote, or a vote informed only by the cover page of the offering circular.

Institutional-sized holdings, the requirement of readily-available investor information, and evaluation costs considerably lower than $\$ 500,000$ should make the vote informed, if not expert. Although rational apathy does not disappear as markets become institutionalized, it is a more serious problem when bonds are held by individuals in small lots. A restructured recapitalization mechanism could have the trustee's designee evaluate the proposal without free-rider problems, by passing evaluation expenses on to the bondholders pro rata, or to the issuer. See infra Section III.

The 1930's regulators believed that the trustee was often corrupt or prone to conflicts of interest. See SEC TRUSTEE REPORT, supra note 20. At that time, the severing of investment banking from commercial banking under the Glass-Steagall Act was a recent innovation; the full implications for trust indentures of the trustee no longer being an underwriter were probably unrecognized. A better regulatory approach than prohibiting bondholder votes might have been to assure further the independence of the trustee by, for example, prohibiting trustee lending to the issuing firm. The SEC suggested this solution, see id. at 107 , but Congress rejected it. The current regulatory direction, however, is contrary to complete severing. See E. Fleischman, Proposed Amendments to the Trust Indenture Act of 1939, at 5-8 (Aug. 10, 1987) (memorandum of SEC Commissioner) (suggesting blanket permission for trustec lending prior to bond default, but requiring resignation upon default); Nash, Glass-Steagall Shift Gaining Support, N.Y. Times, Nov. 9, 1987, at D!, col. 3.

87. Douglas occasionally entertained similar notions. In the early 1930's, he foresaw the eventual emergence of institutional intermediaries as protectors of the bondholders' interests. The institutions would act as a protector directly: Whenever the institution was an intermediary maximizing its investment portfolio's return, it would benefit the intermediary's clients and owners. It would also be an indirect protector whenever the institution maximized the return of its own bonds because it would serve individual bondholders profiting as free riders from its institutional expertise. Douglas, supra note 54, at 573-76. 
expertise and resources, the question becomes one not of institutional competence but of whether institutions will be faithful to their fund holders. ${ }^{\mathbf{8 8}}$

\section{Insider Control}

Today the prospect of undetected direct insider control and voting of a large public firm's bond issue is insubstantial. First, for the insider to favor a shift in value from the bond layer to the stock layer, the insider must have a greater percentage position as a stockholder than as a bondholder ${ }^{89}$ Second, even if direct control were obtained, it would be difficult to engineer a secret vote. .0

If fear of the direct insider remains strong, however, an appropriate remedy would be to ignore insiders' votes when the bond issue votes as a class to recapitalize, with penalties imposed on insiders who try to cast a vote. Congress took a similar approach in the Bankruptcy Code, allowing recapitalizations by majority vote and dealing with the threat of insider control by disallowing the votes cast in bad faith. ${ }^{91}$ Subject to this condition, the Code allows a class to accept any recapitalization by a two-thirds vote in the plan's favor. ${ }^{.2}$

88. The prospect of money managers' disloyalty to their principals, or of side payments, is addressed infra Section II-B-4. Other conflicts are less consequential. Some institutions will not mark their portfolios to market price and accordingly will only "book" the bond's loss when the bond is sold, exchanged or subject to regulatory inquiry. They prefer not to mark-down their investment due to regulatory consequences; the change in book value might induce regulatory inquiry, shut-down, or merger. An exchange of their bond for stock would probably trigger a mark-down, but a change in maturity date might not. Regulatory requirements might thus lead some holders to be primarily concerned with how the bonds are carried on their books, distorting their preference in a restructuring. See Sloan \& Rudnitsky, Taking in Each Other's Laundry, Forbes, Nov. 19, 1984, at 218 (complex exchange agreement arranged so that regulated financial companies will not be required to report losses). Other institutions, such as mutual funds, "book" their bonds daily at current market value (estimating market value when there are no actual trades). See 17 C.F.R. $\$ 270.2 a-4$ (1985).

A related, and perhaps more substantial, risk to an undistorted bond issue recapitalization could arise if an investment bank has monopoly power in a segment of the bond market. The bank may prefer that soured bonds not be booked as defaulted bonds; accordingly it may spend some of its monopoly power to effectuate a recapitalization that avoids a formal default. On an a priori basis, however, it is unclear whether bondholders will be hur by intermediaries agreeing to an undesirable recapitalization, see infra Section II-B-3, or helped by bondholders receiving enhanced consideration to induce them into a workout that avoids a formal default.

89. For example, if an insider who owns $40 \%$ of the stock votes a $51 \%$ majority of the bonds to reduce interest, the insider gives away approximately $11 \%$ of the interest reduction to outsider stockholders. Similarly, anyone who owned a greater proportion of stock than bonds would have an economic incentive to favor value-transferring recapitalizations. The "insider" could be an aggregate of those uncommon investors or intermediaries who directly owned stock and bonds in the same company.

90. The potential for insider destruction of bond issues seems greater for a small firm making a small bond issue. Insiders can obtain the smaller amount of capital necessary to control both the bond issue and the stock issue. See, e.g., Aladdin Hotel Co. v. Bloom, 200 F.2d 627 (8th Cir. 1953) (Insiders of small company control both pre-1939 bond issue and stock issue and vote to extend bonds' maturity.). Yet small bond issues are exempt from the Trust Indenture Act's prohibition of majority action clauses. Trust Indenture Act of 1939, 15 U.S.C. $\S 77 \mathrm{ddd}(\mathrm{a})(9)$ (1982). If a voting prohibition prevents the weed of insider machinations, the most fertile ground for insider machinations has been left unprotected.

91. 11 U.S.C. $\S 1126(\mathrm{e})(1982)$.

92. There is one exception to this rule. The individual bondholder can object to the recapitaliza- 
The presence of the bankruptcy judge is not a compelling reason to distinguish reorganizations within bankruptcy from those outside of bankruptcy. Under the Bankruptcy Code, the judge has no authority to review the substantive fairness of the bankruptcy recapitalization plan. The judge ascertains the vote and the other prerequisites to plan confirmation and, if they are met, the plan is confirmed. ${ }^{.3}$

\section{Quasi-insider Control}

While today the threat of direct insider control is insubstantial, quasiinsider control of a bond issue is more plausible. Douglas feared that the investment bank that ran the bondholders' protective committee in a recapitalization would look to the issuer company as a prospective source of business in future issuances of securities. Typically, the firm's managers are allied with the stockholders or creditor groups that will control the reorganized firm. To please the managers, the investment bank might sell the bondholders short.

While quasi-insider problems remain today, this form of the problem probably is not as severe now as it was in the 1920's and 1930's. Today, many institutional holders of bonds can examine the soundness of an exchange offer. Many institutions have no serious hope for future business from the issuing company because the institutions are independent mutual funds, life insurance companies, pension funds, or savings banks that buy the bonds only for their yield and have no corporate finance or lending department that could do business with the recapitalized company. As long as these institutions have little hope of future business or of a quidpro-quo from the presumably corrupt underwriter or from the company, then the potential for frequent quasi-insider abuse is small. Today's prospect of quasi-insider abuse is thus one step further removed than it seemed to be in the 1930's. Fear of corrupt voting would arise principally

\footnotetext{
tion if she fails to obtain the liquidation value of her claim. 11 U.S.C. § 1129(a)(7) (1982).

Note that the bondholder will probably be represented by a committee representing other creditor groups as well and might even be classified with other creditors, the presumed quasi-insiders, during the reorganization. See 11 U.S.C. § 1122 (1982); Brudney, The Bankruptcy Commission's Proposed "Modifications" of the Absolute Priority Rule, 48 AM. BANKR. L.J. 305, 324 n.35, 327 (1974); Dunham \& Borowitz, supra note 14 , at $452-53$.

Quasi-insider domination of the reorganization could lead to squeezing of middle-layer creditors, such as subordinated debtholders. This domination was a basis for requiring each holder to consent to a deviation from payment-in-full. See Brudney, supra, at 328-30. However, under a bond recapitalization, the bondholders would vote as a separate class and not be classified with other creditors.

93. Compare 11 U.S.C. §1129(a)(8)(A) with id. §1129(b)(1) (Fairness review triggered only if two-thirds of creditor class, see id. $\S 1126(c)$, have not approved of the plan of reorganization.). The judge exercises significant direct control only when approving the documentation used to solicit postpetition acceptance of the plan. 11 U.S.C. \& 1125(b). However, the Code again undercuts regulatory control of the acceptance process. The judge, not particularly expert in valuation matters to begin with, see D. BAIRD \& T. JACkSON, supra note 62 , at 605 , is not even required to make an independent valuation of the bankrupt. 11 U.S.C. $§ 1125$ (b). Ordinary controls on securities' issuances are lifted for the bankruptcy disclosure statement. Id. $\$ \S 1125(\mathrm{~d}), 1145(\mathrm{a})(4)$.
} 
from the prospect of a quid-pro-quo from the company, its underwriters, or other creditors. These prospects are examined next.

\section{Intermediaries as Faithless Agents and the Problem of Side Pay- ments to Selected Bondholders}

In today's financial markets, the mutual fund's controlling investment advisor may be an investment bank that has, or hopes to have, repeated dealings with the recapitalized firm. Separation of the advisory division from the corporate finance division in investment banks is incomplete; the advisory division may be under the influence or control of the bank's corporate finance department. Presumably a modern-day Douglas would fear that, even if the institutional advisor could effectively evaluate the recapitalization proposal, the advisor, under the domination of the fee-producing corporate finance department, would not vote faithfully the mutual fund's bonds for the benefit of the mutual fund's owners. Understandings could develop among the handful of dominant actors to vote bonds held in their intermediary the way the lead underwriter of each deal wished. However, even if the resulting corrupt vote were undetectable, this lack of professionalism would be insufficient to make a vote unfair as long as the intermediaries did not control a majority of the bonds and other financial fiduciaries acted professionally.

For other, intermediaries unaffiliated, a modern-day Douglas might fear that corrupt voting would arise from the prospect of a quid-pro-quo from the company or its investment bank: Paying for some bondholder votes, promising business with the company, giving information about an unrelated transaction such as an impending merger, or granting access to an unrelated but valuable deal could each induce consent. The institution's owners actually may benefit from the preference, but minority bondholders could be hurt. Even more subtle considerations might be sufficient. A mutual fund's bondholders are distant and unidentified. The deal-maker at the investment bank a few floors away, on the other hand, is real and is part of the circle in which the financial agents operate. Recent insider trading suggests that the professionalization of Wall Street is hardly complete. ${ }^{94}$

94. See, e.g., Sterngold, Wall Street Is Facing Reappraisal: Insider Scandal Taints Stance of Self-Regulation, N.Y. Times, Mar. 2, 1987, at D1, col. 6. Current case law allows votes to be openly bought, with the firm directly paying those who vote in favor of the proposal. See Kass v. Eastern Air Lines, Civ. No. 8700, slip op. at 11-14 (Del. Ch. Nov. 14, 1986).

Side payments might be offered to only a selected group of bondholders. But the danger of side payments does not justify a voting prohibition; prohibiting the side payment would be better than prohibiting the transaction. The justification for a voting prohibition then becomes the difficulty in detecting side payments. But a prohibition is not so easily justified. In a related vein, recent insider trading abuses have not led to suggestions that trading in stock be eliminated (the analogue to eliminating recapitalization votes), but have led to proposals to increase penalties and enforcement agency resources. Furthermore, the undetectable unfairness that might arise in a vote must be weighed against the unfairness arising from (or despite) a voting prohibition: Individual bondholders may be 
Each modern-day protective fear advanced is open to question. Unlike secret insider trading purchases of stock, the offending votes in a bondholder recapitalization would be public and observable. Even if the side payment for the votes were not be observable, the visibility of a peculiar vote could trigger inquiry. Furthermore, mutual funds face some competitive controls not directly applicable to the insider breaches. Bond funds compete on the basis of heavily-advertised yields. To the extent the quidpro-quo entails giving up bondholder capital in a corrupt exchange, the portfolio manager will displease its own customers and reduce its advertised yield.

Yet whether these controls are strong enough to prevent corrupt recapitalizations does not directly bear on the value of section 316 . At best section 316(b)'s prohibition reaches the problem obliquely. Section 316 prohibits a vote; it does not prevent a mutual fund manager from selling her fundholders short or accepting side payments that hurt minority bondholders. It merely prohibits her from binding the outsiders. In recent years, companies have had hundreds of exchanges and recapitalizations, many not involving distressed companies, without a vote. ${ }^{95}$ If the justification for section $316(\mathrm{~b})$ is fear of faithless fiduciaries, the current cure is misspecified. Section 316 only protects the mutual fund holders by thwarting some distressed recapitalizations outside of bankruptcy. But when the buoying-up effect is less than enormous-when the company has cash and there is something to steal-the recapitalization will succeed and section 316 (b) will prove to be a weak shield against faithless fiduciaries. ${ }^{98}$ Admittedly, when the buoying-up effect is substantial, when the bonds are subordinated and the firm is insolvent or nearly so, the breakdown of the contemplated recapitalization often induced by section 316 affords protection from faithless fiduciaries. But at this point there is less to steal.

Furthermore, the Trust Indenture Act allows the faithless agents for the majority and those obtaining side payments to discard significant protections obtained by the bondholders at issuance: Security and protective covenants can be deleted and the presumably corrupt majority can bind the dissenting bondholders to the giveaway. ${ }^{97} \mathrm{~A}$ threat to remove these covenants can force bondholders into an otherwise unwanted exchange, notwithstanding section 316. As a protective measure, section 316 is incomplete..$^{88}$

hurt because of disparate treatment in a whirlwind recapitalization that leaves the individuals behind while the exchanging bondholders receive enhanced consideration. See supra Section I-D (Exit consents and thin residual trading market induce assent to exchange offer.).

95. See The First Boston Corp., Report on Exchange Offers 49-69 (undated).

96. That is, section $316(b)$ is a weak shield for those bondholders who will see their fiduciaries trade their bonds away for inadequate consideration. It is a perfectly good shield, in a recapitalization not involving exit consents, for the minority bondholders who hold their bonds directly or through faithful fiduciaries, and who do not exchange their bonds.

97. See supra Section I-D.

98. Perhaps section 316 is more a symbol of bondholder autonomy and indignation over corrupt 
One reaction to these distortions might be to enact a new set of prohibitive regulations. Fund managers could be prohibited from voting in recapitalizations. All recapitalizations outside of bankruptcy could be prohibited. Chapter 11 could be amended to require a valuation hearing by the bankruptcy judge or administrative authorities. ${ }^{9 \theta}$ However, the modern trend has been to remove the administrative apparatus from the reorganization/recapitalization process. Prohibiting the votes of fiduciaries, or passing through the vote to the uninformed mutual fundholder, does not seem a likely, or supportable, prospect in the near future. ${ }^{100}$ Congress removed the requirement of a formal bankruptcy valuation hearing in 1978.

These problems may well be intractable and systemic. As the financial system reticulates, new complex sets of agents interpose themselves between the upper middle class providers of capital and the enterprises using that capital. ${ }^{101}$ Flexibility in the movement and terms of repayment for capital in a complex financial market may be desirable in the name of efficiency and change. Yet flexibility gives the agents an opportunity to benefit at the moment that changes in the pre-established flow of funds are warranted.

No comprehensive solution may be available. But unless the political system is willing to tolerate a set of controls on the consents of financial agents more extensive than that of section $316(\mathrm{~b})$, the policy choice at hand is limited to continuing section 316(b)'s misspecified, incomplete control or replacing it. When we frame the choice in this limited fashion, the benefits associated with facilitating recapitalization tilt the balance in

recapitalizations than a substantive protection.

Requiring, rather than prohibiting, a vote could sometimes discourage bondholder theft. Corrupt intermediaries can now sell bondholders short by tendering into a bad exchange offer. As noted earlier, distressed exchanges outside of bankruptcy typically have a condition of an $80 \%$ minimum bondholder acceptance; some of these recapitalizations succeed, partly due to the distortion of the choice of bondholders by exit consents and a thin residual trading market. Thus, today a corrupt $40 \%$ may unite with a mistaken $10 \%$ and a manipulated (via exit consents and fear of a thin trading market) $30 \%$ to effectuate an exchange offer. But if a two-thirds or greater vote were required, that corrupt recapitalization (adversely affecting the mistaken, the manipulated and the betrayed) would not occur. The noncorrupt, well-informed bondholders would protect both themselves and some bondholders by forcing the transaction to be fair enough to attract the marginal, noncorrupt intermediary. Only when two-thirds of the bondholders were corrupt quasi-insiders or gave their consents foolishly would a vote with a similar minimum percentage increase the unfairness of a recapitalization. It also may well be that only a fraction of the bondholders are, or are under the control of, quasi-insiders, in which case a vote would regularly both decrease distortion and increase efficiency.

99. I have written elsewhere that chapter 11 ought to be restructured with a sound valuation methodology tied to the sale of the firm's securities (or conceivably the sale of the firm itself). See Roe, Bankruptcy and Debt: A New Model for Corporate Reorganization, 83 Colum. L. REv. 527, 559, 573 (1983). If successful, that change would eliminate many of the problems bond recapitalizations now encounter. Moreover, if bankruptcy were swift-a few months instead of a few years-it would not matter as much what happened in bond recapitalizations.

100. But a modernized Trust Indenture Act that allowed the SEC to act through rulemaking could target the most dangerous votes. See infra Section III-A.

101. Clark, The Four Stages of Capitalism: Reflections on Investment Management Treatises (Book Review), 94 HaRv. L. Rev. 561 (1981). 
favor of repeal, especially given the weakness of the current protection. ${ }^{\mathbf{1 0 2}}$ Since some distortions and risks of fiduciary faithlessness are actually diminished by a vote, ${ }^{103}$ and some distortions and faithlessness could be better reduced by specific regulation than by a blanket prohibition of all core term votes, the case for replacing the current regime with more flexible regulation is strong.

\section{Suppression of Securities Fraud Claims}

The 1930's regulators also feared that the investment bankers in control of the protective committee would suppress the investigation of fraud claims. While bondholders might have claims against the investment bank that underwrote the bonds, or against the issuer for fraud or rescission, the investment bank would hardly pursue claims against itself. With an eye on future business with the troubled firm, the investment bank would be reluctant to pursue an investigation into the misdeeds of the firm's managers or fraud in the bonds' issuance. ${ }^{104}$

The voting prohibition is less likely to be crucial in vindicating fraud claims today than it seemed to be in the 1930's. First, a plaintiffs' bar now pursues some fraud claims. Second, today's bankruptcy court will not conduct the searching inquiry into securities fraud that the 1930's SEC wanted and expected to be the natural result of a bankruptcy-inducing voting prohibition. The Bankruptcy Code makes claims against the issuer for securities fraud worthless; in bankruptcy these securities claims are now subordinated to the underlying contract claim. ${ }^{108}$

True, the workout occurs outside of bankruptcy, where the Bankruptcy Code's subordination of the securities law claim is not directly relevant. But since the parties to a work-out know that the firm is on the verge of bankruptcy, the bondholder will understand that the value of the securities law claim is limited in the bankruptcy forum that may follow.

102. But see supra note 6 and infra note 127 (considering possibility that bankruptcy cost savings are not great).

103. See supra note 98.

104. See SEC COMmitee Conflicts Report, supra note 55, at 496, 503, 50\%, SEC STRATEGY REPORT, supra note 52, at 157-59, 787-88, 863; W. Douglas, supra note 58, at 208-09; Swaine, "Democratization" of Corporate Reorganizations, 38 Colum. L. REv. 256, 257-58 (1938).

105. 11 U.S.C. \& 510(b) (Supp. 1987); see Slain \& Kripke, The Interface Between Securities Regulation and Bankruptcy-Allocating the Risk of Illegal Securities Issuance Between Securityholders and the Issuer's Creditors, 48 N.Y.U. L. REv. 261 (1973). If subordinated bondholders were fraudulently induced to buy their security, they would have a fraud or rescission claim against the issuer outside of bankruptcy; the separate fraud claim would not be subordinated inside bankruptcy. The new Bankruptcy Code, however, destroys the value of the separate fraud or rescission claim inside bankruptcy. Although the issuer's claims against fraudulent management or negligent auditors would still be valuable to the bankrupt estate, the reorganization committee today is not the exclusive prosecutor of such derivative claims. 


\section{Protecting Bondholders}

The dominant 1930's reorganization thinkers, in the name of bondholder protection, stopped bondholders from renegotiating their claims. Their inquiry into why large majorities of the bondholders would compromise their contractual right to take the entire firm (pro rata with any other creditors, subject to intra-creditor agreements on priority) was incomplete, focusing only on the potential for theft and insider dealing.

An alternative hypothesis for this bondholder behavior is that the legal structure to enforce bondholder claims is ineffective. Bondholders do not fare as well in bankruptcy as their contracts provide. But when bondholders recognize the partial ineffectiveness of the bankruptcy weapons at their disposal and wish to vote to readjust their claim, the Trust Indenture Act prevents cheap settlement. The proper place to begin bondholder protection is in the Bankruptcy Code; enhanced bondholder protection inside bankruptcy would presumably be transmitted to strengthen the bondholders' negotiating hand in workout settlements. ${ }^{108}$

Forcing a company into bankruptcy as a precondition to allowing a bondholder vote is tantamount to the following: (1) there is a default on a payment for $\$ 1000$ worth of goods sold and delivered, (2) two-thirds of the payee partnership, operating under a majority voting clause in their partnership agreement, are willing to compromise the apparently valid $\$ 1000$ claim for $\$ 900$ because collection costs are high and they want money now, and (3) absent unanimity, a statute requires a lawsuit that the partnership majority expects will cost $\$ 150$. That is probably not the kind of protection the partnership or bondholders especially want. ${ }^{107}$

What are the defects in bondholder protection embedded in the Bankruptcy Code? First, bankruptcy valuation does not correspond to a hard market value, and historically bankrupts are said to be overvalued in reorganization. ${ }^{108}$ As a result, junior interests that would otherwise be eliminated are allowed to participate; higher ranking creditors are thereby undercompensated. ${ }^{100}$ Second, the current framework for reorganization gives managers, presumed to be allies of shareholders, substantial control

106. But see infra note 113.

107. A partnership might adopt a rule of unanimity. Signalling and agency considerations might induce bondholders to allow holdouts. See infra Section III-B-2.

108. E. Altman, supra note 8, at 133; Blum, The Law and Language of Corporate Reorganization, 17 U. CHI. L. REv. 565, 577-79 (1950); Brudney, The Investment-Value Doctrine and Corporate Readjustments, 72 HARv. L. REv. 645, 672-73, 693-94 (1959); Note, Absolute Priority Under Chapter X-A Rule of Law or a Familiar Quotation?, 52 Colum. L. REv. 900, 904-07 (1952). When the bondholders are subordinated and low on the priority list, overvaluation may actually help them.

109. See Blum, supra note 108, at 595; Blum, Some Marginal Notes on TMT Trailer Ferry Reorganization: The New Math?, 1968 Sup. CT. Rev. 77, 84-87 (Undervaluation unlikely because juniors would "buy" firm from those who would take it all via undervaluation; when juniors "let" seniors take firm they do so because they believe firm is not worth more than judicial value accorded it.); Brudney, supra note 92, at 311, 320; Miller, The Wealth Transfers of Bankruptcy: Some Illustrative Examples, LAW \& Contemp. Probs., Autumn 1977, at 39, 41-42. 
over the reorganization process. Managers might delay in hope of an economic upturn and a resurgence of the bankrupt firm. Third, interest on unsecured debt normally does not accrue in chapter $11 .{ }^{110}$ Fourth, bondholders cannot be sure of how their claims will be classified. They have to fight to avoid classification with other creditors, which would dilute the bondholders' vote. Indeed, subordinated bondholders have to fight to avoid both disenfranchisement by being placed in a pool with seniors who will vote the bonds in the bankruptcy, and classification, and hence vote dilution, with other groups of creditors. ${ }^{111}$

Workouts occur in the shadow of bankruptcy. The structural weakness of bondholder protection in bankruptcy-and not insider deals and misinformation-may best explain the poor deal that bondholders obtain in a pre-bankruptcy workout. ${ }^{112}$ Bondholders have little power to obtain much more in a pre-bankruptcy workout than they would receive in their alternative, chapter $11 .{ }^{113}$

110. 11 U.S.C. $\S \S 502(\mathrm{~b}), 1124(3), 1129(\mathrm{~b})(2)$ (C)(ii) (1982). A technical argument may be made that chapter 11's requirement that impaired bondholders receive the liquidation value of their claims imports into chapter 11 the liquidation chapter's interest accrual provision, which is more favorable to bondholders than chapter 11. Compare id. (Size of claim in bankruptcy does not include interest accruing after bankruptcy filed.) with id. $\S 726(\mathrm{a})(5)$ (If assets remain in estate after all claims are paid, interest paid at legal rate from date of filing.).

111. Cohn, Subordinated Claims: Their Classification and Voting Under Chapter 11 of the Bankruptcy Code, 56 AM. BANKR. L.J. 293, 294, 307-09 (1982); Dunham \& Borowitz, supra note 14, at 445 n.34, 456 n.63; see also 11 U.S.C. \$ 1102(a)(1) (1982) (Single creditors' committee often represents all unsecured creditors.).

112. Bondholders also do poorly because the firm's operational value has declined, leaving insufficient value to compensate all claimants fully; bondholders and their allies may then seek to blame the institutional framework for the investment misfortune.

113. The hold-up value of the stockholders in bankruptcy may be the best justification for Douglas' putting the bondholder class outside the arena of negotiation inside bankruptcy, see Case v. Los Angeles Lumber Prods., 308 U.S. 106 (1939), and outside bankruptcy under the Trust Indenture Act. The stockholders' hold-up value is balanced by institutionalizing a countervailing bondholder hold-up value. See Brudney, supra note 92, at 325-26. After 1978, the countervailing hold-up theory lost much of its force by the Bankruptcy Code's two-thirds class vote, ending the single creditor's holdout value in bankruptcy. However, scenarios could be constructed where the operational or distributional costs of bankruptcy fall disproportionately on parties other than the bondholders, making those parties more willing to allow bondholders to be paid better in a workout than in a bankruptcy.

A related question might arise as to whether the majority action clause would facilitate opportunistic shareholder behavior. Shareholders might default and then seek to reduce their obligations to bondholders. If the firm is not a candidate for bankruptcy, bondholders presumably would invoke normal methods of enforcing contracts. When the firm is a bankruptcy candidate, bondholder weakness in bankruptey would be more easily transmitted into the recapitalization with a vote than without a vote. Again, enhancing bankruptcy bondholder protection may be the better method of protecting bondholders. However, scenarios could be imagined in which the indentures' protections are incomplete but bondholders cannot yet force a bankruptcy. Shareholders (or other claimants) might seek to manipulate that gap if they could deal with the bondholders more readily than they can now. That is, no default (which could allow bondholders to accelerate their claim and obtain remedy or bankruptcy) may have occurred, but the firm may approach bondholders, asserting that it will take action detrimental to the bondholders unless bondholders accede to a change in the indenture. That opportunistic shareholder action might be facilitated by a vote, but only so long as such gaps really exist and cannot be closed ex ante by writing a tighter bond indenture.

And we must remember that even today, without majority action, bondholders are not left untouched outside of bankruptcy; techniques are available to cajole bondholders into a non-bankruptcy recapitalization. See supra Section I-D. 


\section{G. Institutional Comparisons: Mergers}

Mergers, tender offers and squeeze-outs present questions similar to those presented in bond exchanges about the extent to which a class of investors can--or ought to-act by majority vote. Comparison of the regulation of mergers with the regulation of bond recapitalization emphasizes the peculiarity of the prohibition on bondholder majority action.

In a standard arm's-length, friendly merger a majority of shareholders vote, upon recommendation of the board of directors, to validate the sale or merger of the shareholders' firm. Only when public policy considerations arising from third-party effects are at stake-antitrust regulation comes to mind-is the majority vote upset in such true arm's-length mergers. Since the 19th century, corporate enabling acts have permitted merger and sale of a firm's assets by shareholder majority vote. ${ }^{114}$ Why should bondholders and the firm be denied that flexibility? ${ }^{115}$

In hostile tender offers, the target firm's shareholders do not formally vote. The target firm's board refuses to recommend the merger to its shareholders; the offering firm does not, and cannot, seek a shareholder vote, but offers to buy up the shares. This structure of tender-offer regulation-effectively precluding a vote-is often said to facilitate actions that the majority of shareholders do not want. In deciding whether to tender, shareholders must consider not only whether they want the offer to go forward, but also whether they want to be left behind in the position of a minority shareholder if the offer succeeds without their particular tender. Since, this widely accepted argument continues, corporate law has been unsuccessful in fully protecting minority shareholders when insiders control the majority of a firm's shares, shareholders will often tender their shares into an offer not because they want the offer to succeed, but because they fear the consequence of remaining as a shareholder if the offer succeeds. $^{116}$

114. See Lauman v. Lebanon Valley R.R., 30 Pa. 42, 45-47 (1858). See generally A. FREX, J. Choper, N. Leech \& C. Morris, Cases and Materials on Corporations 1143-44 (2d ed. 1966) (majority's right to merge not absolute); Eisenberg, The Legal Roles of Shareholders and Management in Modern Corporate Decision Making, 57 CALIF. L. REv. 1, $76-79$ (1969) (discussion of statutes requiring majority approval of merger).

115. Again, such flexibility might not be used. Adverse selection and agency costs might nevertheless lead bondholders to spurn the flexibility to alter the contract before maturity. See infra Section III. Alternatively, increased flexibility might cost the firm 25 basis points in the interest rate; some firms might find that too expensive.

A distinction worth noting is that in an arm's length merger, the board of directors recommends a merger to shareholders; in the formal model, this provides guidance to uninformed shareholders. Formally, the shareholder information and free-rider problems are solved by the board of directors. Reality diverges from formality principally due to managers' conflicts in recommending a merger that would affect their own jobs. In the bondholder setting, a trustee designee who would recommend the exchange (or not) to bondholders could realistically serve a role analogous to the board's formal role. See infra Section III.

116. Some of the bond workouts that succeed use a mechanism analogous to the two-tiered tender offer described in the text. The offered security is a bond that is senior to, or matures earlier than, the target bond. See supra Section I-D. 
Many tender offer critics seek not to prohibit, but to require, a majority vote or its equivalent. ${ }^{117}$ In both basic bond recapitalizations and tender offers, the lack of a voting mechanism distorts decisionmaking, but in opposite ways. In the tender offer, the holdouts often get hurt, creating a rush to tender. In the straightforward stock-for-bond recapitalization, the holdouts are buoyed up, creating resistance to recapitalization. In both transactions the decisional processes are distorted. A majority vote would reduce the distortion in recapitalizations.

\section{Would Regulatory Repeal Make a Difference?}

On balance, the arguments advanced thus far favor ending the Trust Indenture Act's prohibition on majority action clauses. Several questions remain: What form should repeal take? In the absence of prohibition, how much more successful would workouts be? How should bonds that have already been issued be treated? ${ }^{118}$

117. See, e.g., R. Gilson, The Law and Finance of Corporate AcQuisitions 43-47 (Supp. 1987); Bebchuk, Toward Undistorted Choice and Equal Treatment in Corporate Takeovers, 98 Harv. L. Rev. 1693 (1985); Brudney \& Chirelstein, Fair Shares in Corporate Mergers and Takeovers, 88 Harv. L. REv. 297, 337 (1974). Not all commentators think that the lack of a vote is pernicious on an ex ante basis. See Easterbrook \& Fischel, Corporate Control Transactions, 91 Yale L.J. 698 (1982).

Some critics favor more severe controls when a controlling shareholder will cast a vote in a squeezeout of the minority shareholders. See, e.g., Brudney, Equal Treatment of Shareholders in Corporate Distributions and Reorganizations, 71 CALIF. L. REv. 1072 (1983); Brudney \& Chirelstein, A Restatement of Corporate Freezeouts, 87 YALE L.J. 1354 (1978); Lowenstein, Management Buyouts, 85 Colum. L. Rev. 730 (1985). However, the squeeze-out is not precisely analogous to the bond vote. First, direct insiders are few for bond votes. Second, leaving the heavily institutionalized bond market to write its own contract in a recapitalization does not imply that regulation is unneeded to protect scattered, less institutionalized shareholders from the actions of insiders. Compare Federal Reserve Financial Holding Data, supra note 85, at 34 (lines 9-10) (Equity holders are only 35\% institutional.) with sources cited supra note 85 (Junk bond holders are $95 \%$ institutional.). See generally Brudney, Corporate Governance, Agency Costs, and the Rhetoric of Contract, 85 Colum. L. REv. 1403, 1427-28 \& n.62 (1985) ("The problem of restricting the self-interested behavior of an agent (manager) for a residual owner (stockholder) is entirely different . . . when the agent is the residual taker (common stockholder) and the principal is the lender (bondholder). More can be left to contract in the latter case....").

Distortive shareholder transactions, usually involving insiders, are the strongest justification for an appraisal remedy. See, e.g., Fischel, The Appraisal Remedy in Corporate Law, 1983 AM. B. Found. RES. J. 875, 878-79. If votes with across-the-board effects and without insiders, not distortive transactions, were used, a bondholder appraisal remedy has little justification. Appraisal, though, would be superior to prohibition.

118. Bases to subject the bond indenture to regulation follow. Although suggestive, they do not lead inevitably to the conclusion that regulation is needed. (1) The completely contingent indenture cannot be written; open-ended terms fill gaps in the indenture, but arguably the judiciary has not yet adequately viewed the bond indenture as a relational contract where such terms might flourish. (2) Market distortions might develop if bondbuyers, especially individuals, who want a voting clause to be conditioned on the trustee's independence and informed review, cannot readily recognize these terms because they are bondbuyers, not lawyers. See Akerlof, The Market for 'Lemons': Qualitative Uncertainty and the Market Mechanism, 84 Q. J. Econ. 488 (1970). While eventually bar association committees might produce the appropriate standardized clauses, see AMERICAN BAR FoundATION, supra note 41 , this might not occur fast enough for some. (3) Related to the foregoing, the market might not standardize terms quickly, creating evaluation costs for all bondbuyers. (4) Regulators might want to provide the few individuals left in the bond market with some protections that the market would not provide. (5) Some regulatory and political decisionmakers may be reluctant to turn 


\section{A. Repeal}

The minimal legislative change is simple: Repeal section 316(b) and enforce trust indentures as written. While distortions in bondholder action would remain, the bond market could be expected to use contractual controls to deal with the most severe distortions. Even if regulators view the market's contractual reaction as too slow, the Trust Indenture Act's prohibitions are too rigid for rapidly changing capital markets. Openended standards, implemented by SEC rulemaking are better. Future regulatory adjustment should be possible without an act of Congress.

Should there be complete deference to the bond contract? Surreptitious fraud and control abuses are not so threatening that all recapitalization votes should be prohibited; but the prospect of abuse cannot be dismissed out of hand. Insiders should not vote on recapitalizations. Additionally, voting bondholders should be assured, through contract or regulation, that a truly independent trustee has reviewed the relevant papers. Currently, a trustee can be a creditor of the issuing company; this conflict has been a recurrent source of litigation. ${ }^{118}$ Even the votes now permitted can be structured to distort bondholder choice by offering assenting bondholders side payments. ${ }^{120}$

In sum, the current prohibition in section 316 prohibits both too much and too little. Many votes to recapitalize are sound, while some exchanges and votes now permitted by the statute are distorted. A new Rule 316, promulgated after a repeal of section 316 and replacement with a statute prohibiting manipulative and distortive processes in bondholder recapitalizations as interpreted pursuant to SEC rulemaking, might read:

(1) Two-thirds of all the holders (less any holders that are excluded insiders under subparagraph (2)) of any indenture security

from a prohibition to open-ended permission for any contractual result. To obtain repeal of the prohibition, some compromise may be needed.

Reform should also invite inquiry into more global solutions. The tax code's preferential treatment of debt could be altered, reducing the preference for debt over equity financing and consequently reducing the aggregate costs of workouts by reducing the use of debt. See infra Section III-B-4. An alternative global solution would attack the problem of bankruptcy costs directly by fashioning a swift method of reorganizing troubled public firms. See Roe, supra note 99, at 559-600 (offering and analyzing limits of one proposal to do so).

119. Rulemaking might prohibit indenture trustees, at least under indentures allowing for a coreterm vote, from lending money to the company outside of their capacity as bondholders. The Act originally permitted lenders to double as trustees in order to permit the local bank, which might be the best-informed, or the only informed, creditor of the company, to represent the bondholders. For large companies in today's marketplace, enough entities will have adequate information about the firm to separate the functions of trustee and lender. But see supra note 86 (contrary regulatory trend).

120. Could an issuing company give bondholders $\$ 35$ for every $\$ 1000$ face amount of bonds that the holders voted in favor of giving up an important protective financial covenant? The payment, although available to every assenting bondholder, would not go to bondholders voting against the indenture amendment or to those that did nothing. Eastern Airlines did this during its merger with Texas Air. The court held that this was not a violation of Eastern Airlines indenture or any implied contractual terms. Kass v. Eastern Air Lines, Civ. No. 8700, slip op. at 11-14 (Del. Ch. Nov. 14, 1986); accord Pisik v. BCI Holdings Corp., No. 14593, slip op. (N.Y. Sup. Ct. June 25, 1987). 
may by affirmative vote, without side payments and without exit consents, bind all holders of such indenture security to a renegotiation of the terms of the indenture, including a uniformly applicable change in maturity date, principal amount, interest rate or exchange of the indenture security for capital stock of the issuer. No bond shall be issued under an indenture providing for such a vote unless the indenture prohibits the trustee from lending to the issuer.

(2) The vote under subparagraph (1) shall be without regard to the vote of the issuing corporation and of any insider, as defined under Section 101(30) of the Bankruptcy Code, as amended. Prior to the vote, the indenture trustee shall inform the holders of the content of Section 101(30) and provide appropriate interpretive commentary. All holders shall be required to inform the indenture trustee whether they are insiders. ${ }^{121}$

If a defective prospectus were used in the solicitation, securities remedies would lie. ${ }^{122}$ Financial opinions might be required from an independent trustee or its designee, asserting the benefit to bondholders of the exchange. This would make the designee-who could be a large independent bondholder familiar with workouts-the bargaining agent for the bondholders, further alleviating bondholder information and collective action problems. ${ }^{123}$

121. The definition of "insider" might be expanded beyond that in the Bankruptcy Code to include those that do business with the issuer, directly or indirectly, through lending, underwriting or advisory services, or who own more stock proportionately than they own bonds.

Standards of fiduciary conduct make it difficult for trust fiduciaries to hold risky bonds. Nevertheless, the definition of insiders might explicitly include: (a) trust fiduciaries who, while voting their beneficiaries' bonds, own the issuer's stock or have lent the issuer money and (b) trust fiduciaries and anyone else who owns more stock or another security of the issuer than, in percentage terms, they own bonds.

Subparagraph (2) is an enhanced version of the insider protections provided in the one exception to the Trust Indenture Act's current ban on majority action modifying a core term. The exception allows a three-year postponement of interest. Trust Indenture Act of 1939, § 316(a)(2), 15 U.S.G § 77ppp(a)(2) (1982).

122. Cf. Herskowitz v. Nutri/System, Inc., [1986-1987 Transfer Binder] Fed. Sec. L. Rep. (CCH) If 92,829, at 94,036-037 (E.D. Pa. May 13, 1986) (Minority shareholder has standing to bring Rule 10(b)-5 antifraud claim as prospective forced seller if shareholders approve solicited merger plan on basis of misleading press release.).

123. For example, a third paragraph to the proposed Rule 316 might read:

(3) Prior to a vote on recapitalization of the bond issue, the indenture trustee shall distribute to all holders the trustee's recommendation, or the recommendation of a qualified designee that is not affiliated with the issuer and that agrees not to do business worth more than $\$ \mathrm{X}$ with the issuer for three years after rendering the recommendation, as to whether it would accept the proposed recapitalization if the money due under the bond issue were owed to the indenture trustee (or its qualified designee). The reasonable expenses of the trustee in rendering or obtaining such recommendation shall be reimbursed by the issuer. The recommendation shall be accompanied by a statement of the reasons therefor.

The recommendation requirement would effectively stop the issuer from using the majority action clause without first persuading the indenture trustee or its designee that the proposed recapitalization is advantageous for the bondholder. It would be a departure from the largely ministerial function of the trustee today. Alternatives to trustee actions could be found if trustee passivity were too difficult to change.

Since the managers control the recapitalization agenda, they might offer bondholders the minimal amount of payments and rights necessary to attract the required vote. But if the issuer had to engage 
Other distortions arise in workouts. The vote might be structured to induce assent through side payments given only to those who vote favorably. ${ }^{124}$ Alternatively, the company might decline to use a vote but then offer to exchange bonds only to those exchanging bondholders who first consent to indenture changes that would leave the nonexchanging bondholders damaged. ${ }^{125}$ Eventually, one could expect prospective bondbuyers to insist on contractual protections if the distortions became too severe. Yet if reaction through contract did not come quickly enough for regulators, the appropriate regulatory intervention would be exactly the contrary of the current system: Since exit consents and a thin residual market can induce a bondholder to consent to an unwanted deal, if there were to be regulatory intervention at all, it should make voting the exclusive mechanism for some classes of recapitalization.

Furthermore, if contractual reaction is slow and inept-if only because the completely contingent voting clause cannot be written-the best response would not be the imposition of another unbargained-for rigidity in the contract itself. Instead, SEC regulations, which could be altered if ineffective or too costly, could be used to prohibit manipulative and distortive devices in bondholder recapitalizations. The possibility of broken recapitalizations due to holdouts or of two-tiered offers that hurt holdouts is great; our legislation prohibiting all votes on core terms, but allowing exit consents on all other terms, is inflexible.

\section{B. Other Frictions to a Successful Workout}

\section{The Generality of Holdout and Coordination Problems}

A voting mechanism would allow bondholders to act as a single class in workouts without distortive decisionmaking. Bondholders could negotiate with other creditor groups, each agreeing to some form of recapitalization, contingent on the assent of the other creditor groups. Nevertheless, the public firm bankruptcy would hardly disappear if the prohibition of ma-

\footnotetext{
in face-to-face bargaining with a single creditor, the creditor might have an opportunity to impose her result by making a counter-offer. The recommendation requirement would help create that kind of bargaining framework, as well as improve the quality of the information going to the bondholders. Such a bargaining framework might be justified either as fair, by better assuring a good deal for bondholders, or as efficient, by reducing issuer incentives to engineer value-shifting deals that are socially wasteful. Similar mechanisms have been proposed to ameliorate the bargaining disadvantages of scattered shareholders. See, e.g., Brudney, supra note 117, at 1133; see also Brudney, supra note 92, at 314 (Unorganized bondholders may be out-traded by common stockholders, who act through focused cohesion of firm managers.); Leebron, Games Corporations Play: A Theory of Tender Offers, 61 N.Y.U. L. REv. 153, 188-90 (1986) (In noncompetitive tender offer, most of gain from transaction will accrue to bidder because target shareholders cannot coordinate their strategies effectively.); Lowenstein, supra note 117 , at $730-32$ (In going private transaction, "fragmented public investors ha[ve] no mechanism for collective bargaining.").

124. See Kass v. Eastern Air Lines, Civ. No. 8700, slip op. at 11-14 (Del. Ch. Nov. 14, 1986) (Side payment distorts but does not invalidate vote.); supra note 120.

125. See Katz v. Oak Indus., 508 A.2d 873 (Del. Ch. 1986) (exit consent not impermissibly coercive).
} 
jority action clauses were repealed. Decline in industry demand, firm mismanagement, poor labor relations, and mistake are the basic causes of bankruptcy.

Crucial negotiating obstacles other than the bond indenture impede a deal outside of bankruptcy. As we have already noted, even two-party bargains can fail. More difficult multi-creditor bargains will be typical of the public company with several bond issues, a bank syndication, and several major trade creditors. All these creditor classes will be subject to the buoying-up effect, even if each bond issue can act through a vote as a single creditor. Each creditor group will be reluctant to agree to a renegotiation of terms unless the others do so simultaneously. If any of the bargaining defects, such as disparate expectations, mutual mistrust, or strategic holdout to seek buoying up, arise, then a deal may fail. ${ }^{126}$

Furthermore, the cost savings from a recapitalization have not yet been demonstrated, although they are widely believed to be substantial. ${ }^{127}$ But the costs saved are not all public costs. Some are shifts in value from the distressed firm to healthy firms. And if the asset preserved is not a viable operation worth continuing, but a tax asset arising from an unused net operating loss carry forward, then private incentives do not match public goals.

126. Some firms will also have significant nonfinancial creditors that would benefit from the buoying-up effect. Creditors (and shareholders) of a firm with significant tort obligations or labor contracts would be subject to the negative effects of buoying-up. If the financial creditors were to agree to a recapitalization, they would assure better payment to the tort claimants and to the company's workers. Once again, though, these problems are not universal. At least in the labor case, labor can be viewed as one more set of claimants on the firm that can, and do, bargain during the workout, often reducing their claims.

Institutionalization of the bond market alters another aspect of the bargaining dynamic. Conventions and cooperative norms from repeated plays in workouts may facilitate a successful workout despite the incentive to hold out. See R. Hardin, Collective Acrion 155-72 (1982).

127. See Gordon \& Malkiel, supra note 6, at 135-38; F. Allen, Capital Structure and Imperfect Competition in Product Markets (unpublished manuscript). But see Haugen \& Senbet, The Insignificance of Bankruptcy Costs to the Theory of Optimal Capital Structure, 33 J. Fin. 383 (1978) (In absence of recapitalization costs, bankruptcy costs disappear.).

Perhaps the most important reason to doubt whether regulatory repeal would make much of a difference is that repeal might offer limited cost savings. Bankruptcy is usually a reflection of operational decline. The frictions of bankruptcy exacerbate the decline, but most observable costs are not the result of the bankruptcy system itself but of the firm's poor prospects. Although repeal of section 316(b) would make a successful workout more likely, the cost savings would only be the difference between the frictional costs of bankruptcy and the presumably reduced frictional costs of workouts.

Bankruptcy costs conceivably could be the 20th century financial economists' ether: We have never seen them (other than the substantial administrative costs for lawyers and accountants), we do not know exactly what they might be (but we do have some suspicions, such as loss of suppliers, customers and managers), but we cannot explain other significant institutions unless they exist.

However, even if such costs do not exist, or if they do exist but facilitating a pre-bankruptcy workout does not reduce them very much, then, although there is less utilitarian value to a sound recapitalization system, the problem of dispute resolution remains.

Moreover, conceding that high bankruptcy costs are not a proven phenomenon does not alter the best evidence that frictional costs should not be underestimated. Firms scramble to avoid a bankruptcy. Absent tax effects, maybe this is sufficient evidence of its costliness. 


\section{Reasons Not to Use a Majority Action Clause: Signalling and Agency Costs}

Firms and their managers often have a better notion than outsiders, such as prospective bondbuyers, of the firm's prospects. A firm's capital structure has been taken to be a signal of the managers' and insiders' expectations for the firm. ${ }^{128}$ Prospective bondbuyers may take the majority action clause to signal managers' belief in a bleak future. Bondbuyers may think that a firm that asks for a majority action clause does so because its managers seriously fear a decline in the firm's fortunes.

Furthermore, a junk bond with a majority action clause could create related agency costs. Managers-the agents of the corporation-who obtained a majority action bond would succeed in easing the difficulty of a workout, thereby giving themselves a little less inducement to avoid the future difficulty that might result in nonpayment to bondholders. The inability easily to effectuate a workout may be an ex ante advantage, representing a credible commitment at the time of financing to operate the firm well, or suffer the cost of bankruptcy. In a sense, managers offer the firm-or their careers-as hostage to the bondholders. ${ }^{128}$ The ex ante agency benefits of prohibiting a vote could outweigh the expected ex post stress costs of a resulting bankruptcy. ${ }^{130}$

128. See Ross, The Determination of Financial Structure: The Incentive-Signalling Approach, 8 BELL J. ECON. 23 (1977). Financial economists hypothesize that a strong dividend policy, despite its adverse tax consequences, signals that insiders expect good future operations. John \& Williams, Dividends, Dilution, and Taxes: A Signalling Equilibrium, 40 J. Fin. 1053 (1985); see also Easterbrook, Two Agency-Cost Explanations of Dividends, 74 AM. EcoN. REv. 650 (1984) (signalling and agencycost explanations of dividends); Levmore, Monitors and Freeriders in Commercial and Corporate Settings, 92 YALE L.J. 49 (1982).

129. See T. Schelling, supra note 17, at 136-37; Kronman, Contract Law and the State of Nature, 1 J.L. ECON. \& ORGANIZATION 1, 12-15, 18-20 (1985) (Hostages and hands-tying support exchange.); Williamson, Credible Commitments: Using Hostages to Support Exchange, 73 AM. ECON. REv. 519, 532 (1983). Each financing alternative will have its own disadvantages. Managers will choose from among the less-than-perfect alternatives. The negative agency cost and signalling hypotheses are drawbacks of majority action clauses. The clauses still might be used.

Since alternative financing mechanisms are now available, do firms that issue bonds today want the prohibition on majority action clauses? Are they signalling their good prospects to bondholders and other financial owners of the firm? For example, private placement of bank debt is not subject to the severe holdout problems of public debt during a workout. See infra note 130 . This makes bank debt attractive; but bank debt usually matures in only a few years, while bond debt can be outstanding for twenty years. Issuers must choose among the disadvantages. See Weiner, Junk Bond Debate Worries Growth Firms, Am. Banker, Dec. 26, 1985, at 5, col. 2 (Bankers lend short-term at rates higher than prime rate; junk bonds are long-term.).

130. Bank syndications usually do not have a majority action clause and accordingly might be seen to support the view that the clause would not be used. Although the text's agency and signalling rationales might be the explanation for the absence of the clause in bank syndications, it does not follow that the clause would fall into disuse in bond issues. A bank syndication is more easily renegotiated than a bond issue. First, members are readily identifiable and can be brought together in the same room and deal with one another repeatedly, creating social sanctions against holdouts. Cf. $R$. AXElRod, The Evolution of CoOperation 177-78 (1984) (Repeat games among same actors foster cooperation.). Institutionalization of the bond market may eventually create a similar effect. Second, bank holdouts can be bought out by other members of the bank syndicate that want a deal done. The syndicate leaders have more of a financial and reputational stake (as effective syndicate leaders) than does the bondholders' trustee in seeing that the workout succeeds. 


\section{Transition and Elasticity}

If a change in the Trust Indenture Act were implemented only prospectively, affecting bond indentures when written, as the Act now does, full transition would take years. Billions of dollars of junk bonds already are outstanding; some of the additional billions of ordinary bonds now outstanding will turn sour before maturity. Unless a future Congress were willing to upset contracts in place, the workout problems of the 1990's will have to be attended to today. Although similar policy changes are often implemented by amending a regulation, under our normal jurisprudence we are reluctant to alter contracts already in place. ${ }^{131}$

Third, holdout banks face economic sanctions. Syndicate leaders often can force recalcitrants to accept the deal the syndicate leaders negotiate: "[A] 'search and destroy' campaign [was used] against [Chrysler's] holdout banks. . . . [C]ontinued resistance could gain [a bank] a reputation as a 'bad actor,' which would likely keep it out of future syndicated credits." R. REICH \& J. DoNAHUE, supra note 15 , at 189.

Bank syndication agreements may allow holdouts for several reasons. First, syndicate signalling may be enhanced. The lead bank can signal the smaller banks that the lead bank considers the credit good by according the smaller bank holdout value (diminished by the social and economic sanctions). Second, custom, perhaps established in times of greater negotiability or regulatory considerations than today, is not easily upset. Third, the debtor firm may be signalling belief in its own financial strength.

131. Changes occur in merger and tender offer regulation, but do not raise contractual alteration and "takings" issues. The bond indenture problem arises because of the jurisprudentially peculiar manner of the regulation: The Trust Indenture Act operates not through legal fiduciary standards or regulation of actions in a recapitalization but through requirements of what must and must not be in the contract. Whether the bankruptcy power can be asserted without a formal proceeding might be a question for inquiry.

See generally Kaplow, An Economic Analysis of Legal Transitions, 99 HaRv. L. REv. 509, 584-88 (1986) (criticizing widespread grandfathering). This is not the place to discuss constitutional inhibitions on upsetting contracts in place. Clearly Congress did upset similar contractual arrangements when it provided for a binding two-thirds vote in the 1978 Bankruptcy Code. See also United States v. Security Indus. Bank, 459 U.S. 70, 74-75 (1982) (Rehnquist, J.) (While bankruptcy power might not allow taking of things traditionally considered property, it allows Congress retroactively to upset contracts in place.) (dictum).

As a policy matter, perhaps legislation prospectively ending the Trust Indenture Act's prohibition could craft a compromise alteration of contracts in place, if the tendency to grandfather were overcome. A firm would be allowed to propose to its bondholders that a majority action clause be added, and the bondholders could be permitted to do so by super-majority vote. The addition could not be used immediately, but only after, say, three or five years. Thus the issuer would have to buy the benefit of flexibility from the bondholders.

Why, as a matter of policy, not impose, or at least allow, immediate effectiveness of a majority action clause? Neither bondholders nor issuers bargained for the clause in a traditional sense; they were forced by section 316 (b) to use it. Nevertheless, bondholders tend to do better than other creditors when there is a successful negotiation because the firm cannot negotiate effectively with them outside of bankruptcy on the core issues. See Dunham \& Borowitz, supra note 14, at 445-46 n.34. For example: Chrysler went through a substantial recapitalization during 1980 . Institutional creditors saw their claims slashed and turned into preferred stock and warrants. But public debentureholders' financial claims were left untouched; interest payments were made in full and on time.

To the extent the difference between the bondholders' expected benefit (if there is a successful recapitalization, they do better) and loss (the recapitalization is more likely to fail without a majority action clause) is positive, the firm will have to compensate the bondholder when using a majority action clause. In other words, the bondholders would not, we suppose for the moment, find it ex ante worthwhile to "pay" for the advantages of being unreachable in the event of an attempted workout; but once they have already "bought" that benefit, as they now must, it may seem unfair to take it away by voiding the prohibition on majority action. Also, the prohibition may stop opportunistic behavior that would be addressed by rewriting the indenture if voting were permitted. Perhaps a new bargain, and not wholesale rewriting of contracts in place, should be required. 
Even aside from transition problems, other frictions will impede successful future renegotiations. If allowing majority action clauses decreases a firm's costs of issuing public debt, one could expect issuers to use more public debt than they currently do. The extent to which increased use of public debt, and accordingly the increased later frequency of workouts, would mitigate the decrease in costs of recapitalizations depends on elasticities about which we can only speculate.

\section{Tax Frictions}

Tax frictions could also impede an early workout. As a general rule the exchange of debt for stock whose fair market value is less than the face value of the debt will produce taxable discharge-of-indebtedness income equal to the difference between face and market values. ${ }^{132}$ Exceptions to and reductions in the impact of the discharge-of-indebtedness income are available but usually not until the eve of, or during, bankruptcy. ${ }^{133}$ The troubled firm thus could be expected wisely to wait, not seeking a stockfor-debt workout until on the verge of bankruptcy, ${ }^{134}$ when the tax penalties will be avoided. ${ }^{195}$

This suggests a disheartening scenario: When the firm begins to decline it believes a stock-for-debt workout would be operationally useful. But compared to the hard certainty of increasing its current tax bill, the contingency of future financial gridlock seems more remote. Management accordingly might delay seeking a workout. If it miscalculates and waits too long, or if the operational decline is more severe than expected, or if one of the other impeding frictions arises, then the workout fails.

The convoluted institutional structure governing risky public debt is quite ironic. The favored tax status of debt (interest is deductible, dividends are not) encourages widespread use of debt. The prohibition on bondholder votes makes public debt difficult to renegotiate. Furthermore, tax penalties are incurred if a renegotiation is attempted early, before the holdout problem becomes severe: Discharge-of-indebtedness income will be incurred if a stock-for-debt renegotiation is attempted other than on the eve of bankruptcy. ${ }^{136}$ The tax penalty is lifted if the firm is in, or on the

132. I.R.C. $\S \S 61(\mathrm{a})(12), 108(\mathrm{e})(10)(\mathrm{A})$ (West Supp. 1987); United States v. Kirby Lumber Co., 284 U.S. 1 (1931).

133. I.R.C. \& 108(e)(10)(B) (West Supp. 1987).

134. Or, more precisely, it will wait until its net operating loss carryforward is so substantial that its reduction-via the financial income arising from discharge-of-indebtedness-is an insubstantial cost to the firm, since the carryforward would not have otherwise been used to reduce taxes until years later.

135. A similar tax rule reduces the net operating loss carryforward if a change in ownership occurs, such as by creditors taking a majority of the company's stock. Again, the rule is inapplicable in bankruptcy. I.R.C. $§ 382(a)$, (l)(5) (West Supp. 1987).

136. An early debt-for-debt renegotiation will not trigger these tax penalties. But, as we have seen, informational impediments can be reduced by a stock-for-debt recapitalization, because the company that understates its prospects, to induce bondholders unnecessarily to turn in their bonds, will 
eve of, bankruptcy. But waiting until the eve of bankruptcy for a full recapitalization increases the buoying-up incentives of holdouts; the prisoners' dilemma of bondholders is exacerbated. If the dilemma induces failure of the workout, bankruptcy is available to end it, by allowing, indeed requiring, collective bondholder action and eliminating the tax penalties to recapitalization. The tax code thereby encourages brinkmanship.

\section{Summary}

Possibly, given agency costs, signalling effects and tax consequences, majority action clauses would not be used even if allowed. However, there seems little reason to prohibit firms from using the clause.

Firms did use the clause intermittently in the United States before it ran into negotiability difficulties and the Trust Indenture Act's prohibition. Prior to prohibition, demand for its use was rising. ${ }^{137}$ Firms in Canada and England, countries with financial and legal institutions roughly similar to ours, have used the majority action clause. ${ }^{138}$ Preferred stock, a security with non-tax features similar to low-quality bonds, often contains voting clauses. ${ }^{139}$ Junk bonds with features that relieve some aspects of financial stress are increasingly popular; ${ }^{140}$ presumably firms would seek other features that would relieve stress if the legal system gave permission.

\section{Conclusion}

As junk bonds proliferate, future workouts to recapitalize declining issuers of junk bonds will be attempted. Some issuers of investment grade bonds will suffer dramatic reversals and also attempt to recapitalize. Yet a firm with a large bond issue can be expected to have a harder time recapitalizing than a troubled firm financed primarily with non-public debt.

The legal system creates crucial difficulties for failed bond issues, their holders and their issuing firms. The bondholders cannot act as a class

have to give much of its stock to the bondholders. See supra note 15. Also, the exchange of debt-fordebt will not usually alleviate financial stress as well as an exchange for stock.

137. See supra note 20.

138. 7 Haisbury's LAw of ENGLANd $\$ 849$, at 503-04 (4th ed. 1974); Fraser's Handbook on Canadian Company Law 312 (H. Sutherland, D. Horsley \& J. Edmiston eds. 7th ed. 1985) ("Most trust deeds provide for the modification or compromise of the rights of bondholders by the vote of a stated majority ...") (emphasis added); Billyou, supra note 78, at 595-96; Fraser, Reorganization of Companies in Canada, 27 Colum. L. REv. 932, 934 (1927).

139. I examined the prospectuses of a dozen recent preferred stock issuances; each issue had a voting clause.

140. Some junk bonds allow the issuer the option to pay interest in common stock having a market value equal to the interest due. See, e.g., Altman \& Nammacher, supra note 23, at 13; Bianco, Junk Bonds Are Starting to Live Up to Their Name, Bus. WK., Feb. 17, 1986, at 64, 65 (Crystal Oil); Sharon Steel Corp., Exchange Offer Circular, at 39-40 (May 3, 1985); cf. Sherman, Ted Turner: Back From the Brink, ForTuNe, July 7, 1986, at 25, 30 (Turner Broadcasting pays preferred stock dividends in shares of common stock.); Disclosure Statement Accompanying First Amended Plan of Reorganization of MGF Oil Corp., In re MGF Oil Corp., No. 7-84-02160-E-11, at 90 (Bankr. W.D. Tex. filed June 11, 1985) (proposing preferred stock issue with cumulative dividends payable in cash or common stock, at issuer's option). 
outside of bankruptcy in renegotiating the core terms of their loan to the firm. The legislative history supporting the prohibition is weak because the prohibition's result replicated that of technical regulation under the now-defunct Negotiable Instruments Law.

The individualized bond market of the 1930's-as it was then perceived to be-might have warranted protection from majority votes. But the 1980 's market is vastly different. The dominant holders of bonds are not individuals but institutions that understand exchange offers. The structural change is reflected in the 1978 Bankruptcy Code, which allows a two-thirds majority of a creditor class to bind the entire class. Both the market and Congress have pulled away the supporting rationales for the prohibition.

Today, risks analogous to the 1930's rationale for the voting prohibition persist. A principal one is that the institutions voting bonds in workouts will be unfaithful agents of the bonds' ultimate owners. Looking for collateral benefits, these institutions may vote corruptly. Such corrupt voting would presumably represent an actionable breach, but detection and prosecution arguably are difficult. Another risk is that a vote might be used for those terms that may be voted upon, and side payments might be offered only to those bondholders that vote favorably. But the question is not whether such scenarios are impossible-clearly they are not-but whether section $316(\mathrm{~b})$ provides serious protection against their occurrence. The protection seems weak.

The potential for distortion (buoying-up that benefits holdouts or twotiered offers that hurt holdouts) is substantial, and the fifty year-old legislation prohibiting all votes on core terms is too inflexible to deal adequately with the new realities. Without a majority action clause, the chance increases that workouts will by stymied because some creditors are subject to disparate expectations, mistrust either other creditors or the issuer, or attempt to gain from strategic action. When unable to assure equality among creditors at the same priority level, the parties to a workout are denied one of the natural focal points-equality of treatment-that can help them reach agreement. Furthermore, and most crucially, the buoying-up effect will benefit those creditors who do not participate in a recapitalization at the expense of those who do. This buoying-up may make it necessary that all or nearly all of the creditors agree to the recapitalization. But the prohibition on majority action clauses in public bond issues impedes such near unanimity and provides an incentive to introduce countervailing distortions.

These considerations are speculative. Experiments to measure the benefits of a prohibited bond clause cannot be run. Bond defaults increase as the quality of bond issues declines, but a buoyant economy does not provide the large sample size needed for scientific, statistical comfort. By the time scientific certainty is available, it will be too late: We will then have 
had failed workouts. In an uncertain world we must examine what has already happened and then do our best to formulate policy recommendations. Surely, the general perniciousness and reality of the buoying-up effect cannot be denied. The buoying-up effect conceivably nearly shut down Chrysler, despite the company's plausibly viable operational project; it prevented the Los Angeles Lumber Products Company-the subject of a Douglas decision at the heart of modern bankruptcy doctrine-from building ships; and it precipitated MGF's bankruptcy. When workouts occur on the eve of bankruptcy, high majorities regularly are required, apparently because of the buoying-up effect. In a few nearly pure cases, bankruptcy would have been avoided if a majority vote were permitted.

The overall costs of financial stress are difficult to measure, especially because the widespread use of junk bonds is such a new phenomenon. If bankruptcy costs are low-or if whatever bankruptcy costs exist are experienced in the workout anyway-then the repeal of section 316(b) would achieve little in the way of economic efficiency. The important costs of the prohibition are only the difference between the social costs of a workout and those of a chapter 11 proceeding. Some workouts succeed anyway; some would fail no matter what. And for those that are elastic and amenable to manipulation via section $316(\mathrm{~b})$ who knows whether the difference in cost between the two is very much? Bankruptcy costs have not been seen directly (beyond the direct costs of administration); they are presumed to exist and be substantial because the models cannot explain readily observed patterns of debt and equity without them.

Although the efficiency costs of section 316(b) are speculative, the section accomplishes little in the name of fairness and avoided fiduciary breaches. If section $316(\mathrm{~b})$ offers little protection but nevertheless costs little, it may be seen as a symbol of indignation over financial theft that it nevertheless does little to prevent. It also may be seen as a symbolic gesture toward a stylized autonomy in individual bondholder decisionmaking, permitting individual bondholder recapitalization decisions to be overridden only by expert New Deal regulators and judges, not by other bondholders in marketplace bargains. As symbolism there is an alternative: The intuition that voting to a settlement is as good a way as any other to resolve disputes.

If the protective fairness basis seems weak, and if even the efficiency basis has uncertain strength, there may yet be reason to repeal section 316(b). Disputes arise. Enterprises flounder. Our conclusion may be no more than a burden-shift. A decision on recapitalization must be made. In the absence of compelling bases to intervene, a vote can be taken and the company, the parties, and the system can move on to the next problem. 
